\title{
Late-Quaternary glacial to postglacial sedimentation in three adjacent fjord-lakes of the Québec North Shore (eastern Canadian Shield)
}

\author{
Antoine G. Poiré ${ }^{\mathrm{a}, *}$, Patrick Lajeunesse ${ }^{\mathrm{a}}$, Alexandre Normandeau ${ }^{\mathrm{a}, \mathrm{b}}$, Pierre Francus ${ }^{\mathrm{c}}$, Guillaume St-Onge ${ }^{\mathrm{d}}$, \\ Obinna P. Nzekwe ${ }^{\mathrm{c}}$ \\ a Département de géographie \& Centre d'études nordiques, Université Laval, Québec, Qc G1V 0A6, Canada \\ ${ }^{\mathrm{b}}$ Geological Survey of Canada (Atlantic), Bedford Institute of Oceanography, P.O. Box 1006, Dartmouth, Nova Scotia B2Y 4A2, Canada \\ ${ }^{\mathrm{c}}$ Centre Eau Terre Environnement, Institut National de la Recherche Scientifique, Québec, Qc G1K 9A9, Canada, Canada Research Chair in Environmental Sedimentology \& \\ GEOTOP \\ dinstitut des sciences de la mer de Rimouski, Université du Québec à Rimouski, Rimouski, Qc, Canada, Canada Research Chair in Marine Geology \& GEOTOP
}

\section{A R T I C L E IN F O}

\section{Article history:}

Received 23 June 2017

Received in revised form 31 January 2018

Accepted 11 February 2018

Available online $\mathrm{xxx}$

Keywords:

Fjord-lakes

Deglaciation

Laurentide ice sheet

Swath bathymetry

Acoustic stratigraphy

\begin{abstract}
A B S T R A C T
High-resolution swath bathymetry imagery allowed mapping in great detail the sublacustrine geomorphology of lakes Pentecôte, Walker and Pasteur, three deep adjacent fjord-lakes of the Québec North Shore (eastern Canada). These sedimentary basins have been glacio-isostatically uplifted to form deep steep-sided elongated lakes. Their key geographical position and limnogeological characteristics typical of fjords suggest exceptional potential for long-term high-resolution paleoenvironmental reconstitutions. Acoustic subbottom profiles acquired using a bi-frequency Chirp echosounder $(3.5 \& 12 \mathrm{kHz})$, together with cm- and m-long sediment core data, reveal the presence of four acoustic stratigraphic units. The acoustic basement (Unit 1) represents the structural bedrock and/or the ice-contact sediments of the Laurentide Ice Sheet and reveals V-shaped bedrock valleys at the bottom of the lakes occupied by ice-loaded sediments in a basin-fill geometry (Unit 2 ). Moraines observed at the bottom of lakes and in their structural valleys indicate a deglaciation punctuated by short-term ice margin stabilizations. Following ice retreat and their isolation, the fjord-lakes were filled by a thick draping sequence of rhythmically laminated silts and clays (Unit 3) deposited during glaciomarine and/or glaciolacustrine settings. These sediments were episodically disturbed by mass-movements during deglaciation due to glacial-isostatic rebound. AMS ${ }^{14} \mathrm{C}$ dating reveal that the transition between deglaciation of the lakes Pentecôte and Walker watersheds and the development of para- and post-glacial conditions occurred around $8000 \mathrm{cal} \mathrm{BP}$. The development of the lake-head river delta plain during the Holocene provided a constant source of fluvial sediment supply to the lakes and the formation of turbidity current bedforms on the sublacustrine delta slopes. The upper sediment succession (i.e., $\sim 4-\sim 6.5 \mathrm{~m}$ ) consists of a continuous para-to post-glacial sediment drape (Unit 4) that contains laminated and massive sediment and series of Rapidly Deposited Layers. These results allow establishing a conceptual model of how a glaciated coastal fjord develops during and after deglaciation in a context of rapid glacio-isostatically forced regression.
\end{abstract}

(C) 2017 .

\section{Introduction}

During Quaternary glaciations, fjords acted as preferential pathways for the flow of glacial ice originating from continental ice sheets, leading to the transfer of large volumes of ice and sediments to the marine environment (Syvitski and Praeg, 1987, 1989; Hambrey, 1994; Syvitski and Shaw, 1995; Howe et al., 2010). Fjords can provide a long-term sedimentary record to reconstruct past ice sheet dynamics such as ice-flow and rates of ice retreat or advance (Evans et al., 2002; Howe et al., 2010; Schumann et al., 2012; Dowdeswell and Vásquez, 2013; Dowdeswell et al., 2014). Thick sedimentary in fills in fjords and bedforms preserved at their bottom provide a record of marine and terrestrial glacial processes and depositional environ-

\footnotetext{
* Corresponding author.

Email address: antoine.gagnon-poire@ete.inrs.ca (A.G. Poiré)
}

ment successions that occurred during glacial, deglacial, paraglacial and postglacial times (Boyd et al., 2008; Baeten et al., 2010; Cowan et al., 2010; Forwick and Vorren, 2010; Bertrand et al., 2012; St-Onge et al., 2012; Breuer et al., 2013; Dowdeswell and Vásquez, 2013; Hjelstuen et al., 2013; Kempf et al., 2013; Hodgson et al., 2014; Flink et al., 2015). Fjords have generally been described in coastal and estuarine environments, but they also occur in lacustrine settings when freshwaters are enclosed in preglacial and glacial overdeepened valleys (Nasmith, 1962).

Following deglaciation of coastal regions, some fjord basins were isolated from the sea to form fjord-lakes due to glacio-isostatic rebound (Batterson et al., 1993; Batterson and Catto, 2001; Lajeunesse, 2014; Dietrich et al., 2017b). Sharing similar limnogeological characteristics with coastal fjords, fjord-lakes have shown their potential for reconstructing past ice sheet dynamics, deglaciation, paleoenvironmental changes and natural hazards in studies using marine hydroacoustic, geophysical and sediment sampling analysis techniques, as 
demonstrated in Europe (Van Rensbergen et al., 1999; Beck et al., 2001; Fanetti et al., 2008; Hilbe et al., 2011; Heirman et al., 2012; Turner et al., 2012; Pinson et al., 2013; Vogel et al., 2013), British Columbia (Eyles et al., 1990, 1991; Desloges and Gilbert, 1995, 1998; Gilbert and Butler, 2004; Gilbert and Desloges, 2005, 2012; Gilbert et al., 2006a; Gilbert et al., 2006b; Tunnicliffe et al., 2012), New York State (Mullins and Hinchey, 1989; Mullins and Eyles, 1996; Mullins, 1998; Mullins and Halfman, 2001), Montana (Mullins et al., 1991), eastern Canada (Lajeunesse, 2016) and Patagonia (Kastner et al., 2010; Waldmann et al., 2010; Van Daele et al., 2016).

In eastern Canada, deep fjord-lakes occur in many locations along the formerly glaciated Québec North Shore and the east coast of Newfoundland and Labrador. However, their morphology and stratigraphy as well as their sedimentary processes associated with the transitions from glacial to postglacial environmental conditions during glacial-isostatic rebound remain undocumented. Here we describe the geomorphology, stratigraphy and sediments of three fjord-lakes of eastern Canada: lakes Pentecôte, Walker and Pasteur in order to 1) reconstruct their Late Quaternary morphological and sedimentary evolution in response to deglaciation and glacio-isostatic rebound and 2) establish a deglaciation and sedimentation conceptual model for fjord-lakes under glacio-isotatic rebound. This paper provides the ge- omorphological context and history for a continuous sedimentary record of paleoenvironmental changes in three Québec North Shore watersheds, from deglaciation to the establishment of modern (i.e., postglacial) conditions. The proposed conceptual model serves as an example of how a glaciated coastal fjord develops upon deglaciation, at the interplay of marine and terrestrial settings influenced by a rapid glacio-isostatically forced regression.

\section{Regional setting}

Lakes Pentecôte, Walker and Pasteur are located in the central sector of the Québec North Shore (northwestern Gulf of St. Lawrence, eastern Canada), at elevations of $84 \mathrm{~m}, 115 \mathrm{~m}$ and $86 \mathrm{~m}$, respectively (Fig. 1). They are situated at the downstream end of long $(>60 \mathrm{~km})$ north-south-oriented glacial valleys that are deeply incised into the Precambrian Grenville geological province of the Canadian Shield. The lakes are located in the transition zone between the coastal lowlands and the highlands of the Canadian Shield (i.e., Laurentian Highlands) that reach $>300 \mathrm{~m}$ above sea level (asl) in the study area. The lakes generally form elongated basins with steep sidewalls with morphologies typical of fjords (e.g., potholes and p-forms on their sidewalls; Holtedahl, 1967). The length of lakes Pen-
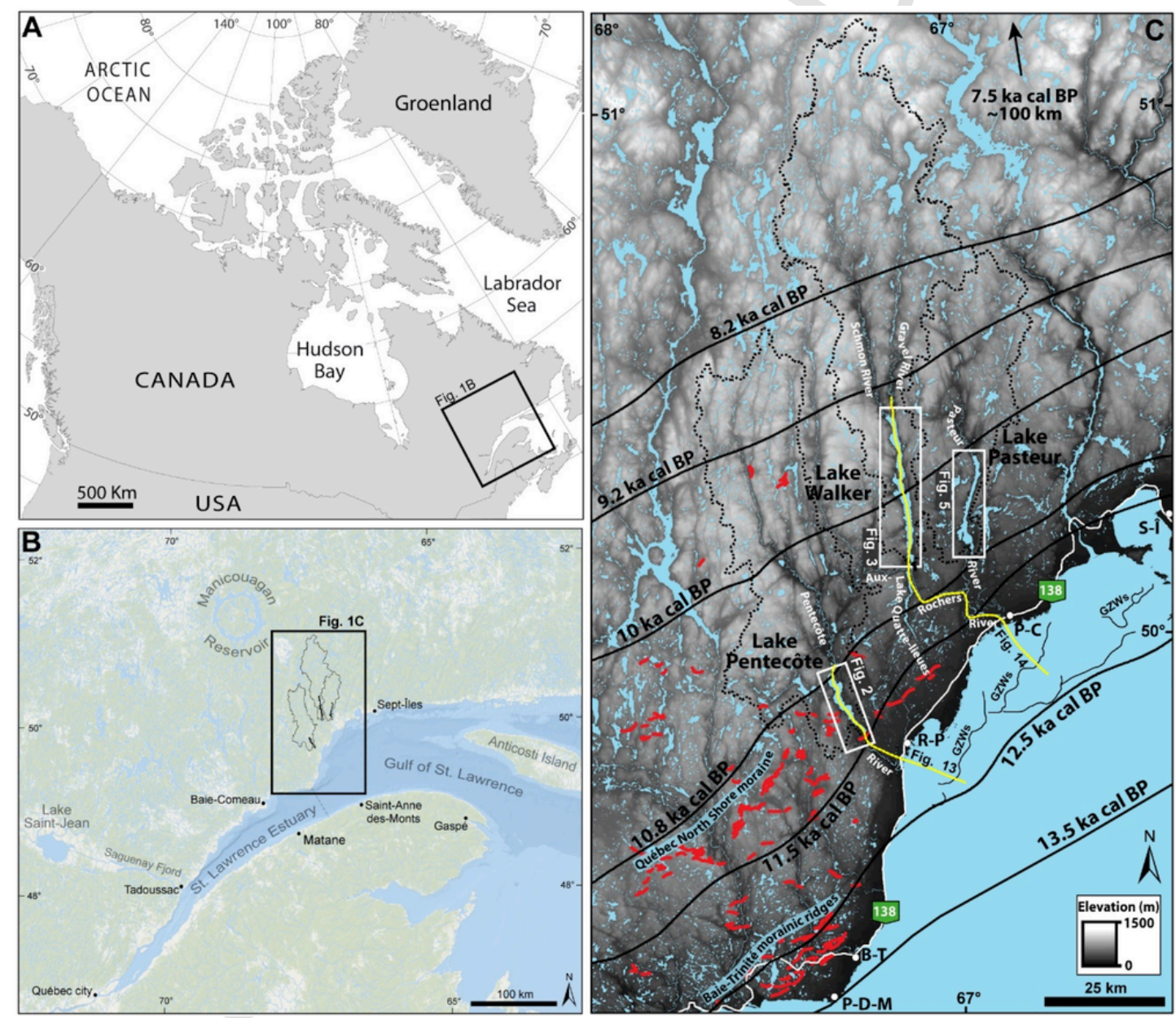

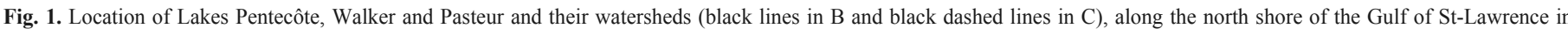

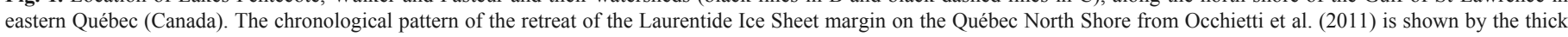

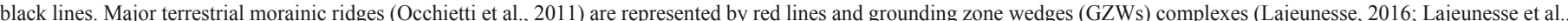

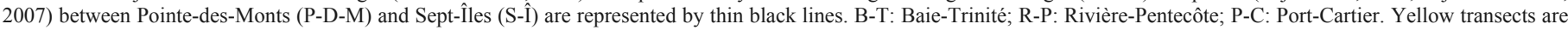
represented in Figs. 13 and 14. (For interpretation of the references to color in this figure legend, the reader is referred to the Web version of this article.) 
tecôte, Walker and Pasteur reach $\sim 15, \sim 30$ and $\sim 18 \mathrm{~km}$, respectively. Lake Walker has the largest watershed covering an area of $1896 \mathrm{~km}^{2}$ compared to $1227 \mathrm{~km}^{2}$ for Lake Pentecôte and $739 \mathrm{~km}^{2}$ for Lake Pasteur. Lakes Walker and Pasteur lie on homogeneous granitic gneiss complexes. Lake Pentecôte lies on different geological suites and complexes composed principally of anorthosite, granite and paragneiss separated by faults (Moukhsil et al., 2011) that probably control structurally the bifurcation of the lake in its center. These fjord-lakes are mainly fed by their head deltas formed by large rivers that discharge into their northern extremities (Normandeau et al., 2016a). The lakes flow into the Pentecôte, aux-Rochers and Pasteur Rivers, respectively, at their southern end towards the Gulf of St. Lawrence (Fig. 1C).

During deglaciation, the marine-based Laurentide Ice Sheet (LIS) margin stabilized slightly offshore along the Québec North Shore to deposit apron-shaped grounding-zone wedges (GZW) (Fig. 1C) (Lajeunesse, 2016). The youngest GZW is probably correlated to the eastward extent of the early Younger Dryas Saint-Narcisse Morainic System deposited between 12.8 and 12.2 ka cal BP in southern Québec (Occhietti, 2007). As ice retreated $\sim 30-50 \mathrm{~km}$ farther north onto the Laurentian Highlands, the LIS margin re-stabilized and deposited the Québec North Shore Moraine (Dubois and Dionne, 1985), a major morainic system correlated with the late Younger Dryas Mars-Batiscan Moraine deposited between 12.2 and $11.5 \mathrm{ka}$ cal BP (Occhietti et al., 2011). Between 11.5 and $10.8 \mathrm{ka}$ cal BP, the LIS margin stabilized near the outlet of lakes Pentecôte, Walker and Pasteur valleys and deposited thick glaciomarine ice-contact outwash fans. The glacio-isostatically flexured lowlands and valleys were submerged by the Goldthwait Sea transgression at a maximum elevation of $130 \mathrm{~m}$ asl (i.e., marine limit) (Dredge, 1983; Hein et al., 1993), reaching the studied lakes between $\sim 11.1$ and $10.6 \mathrm{ka}$ cal BP $\left(9.5{ }^{14} \mathrm{C}\right.$ ka BP; Dubois and Dionne, 1985; King, 1985). Under rapid glacio-isostatic rebound prevailing during the early stage of deglaciation (i.e., $\sim 3.2 \mathrm{~cm}$ $\mathrm{a}^{-1}$ during the first millennia; Dionne, 2001), coastal structural valleys were isolated from the sea allowing the formation of fjord-lakes (Lajeunesse, 2014, Dietrich et al., 2017b). Between 8.2 and $7.5 \mathrm{ka} \mathrm{cal}$ $\mathrm{BP}$, the LIS margin had retreated over the Canadian Shield until it stabilized north of the Manicouagan Reservoir, $\sim 100 \mathrm{~km}$ north of the study area (Occhietti et al., 2011; Ullman et al., 2016). During this period, most major watersheds of the Québec North Shore were undergoing their final stage of deglaciation (Dietrich et al., 2017b).

The investigated lakes are located north of the Lower St. Lawrence Seismic Zone (LSLSZ), where low magnitude $(\mathrm{M}=<5.1)$ historical earthquakes have been recorded (Lamontagne et al., 2003; Lamontagne, 1987). Acoustic stratigraphy surveys previously undertaken by Ouellet (1997) in lakes Pentecôte, Walker and Pasteur led to the observation of only a limited number of subaqueous mass-movements deposits near the upper boundary of deglacial sediments; they have not been observed in Holocene sediments.

\section{Methods}

\subsection{Hydroacoustic and geophysical data}

High-resolution bathymetric data were collected in 2011 in Lake Walker and 2014 in Lake Pentecôte, on the $8 \mathrm{~m}$-long R/V Louis-Edmond-Hamelin using a Reson Seabat 8101 multibeam echosounder $(240 \mathrm{kHz})$, the Hypack ${ }^{\circledR}$ software, an Ixsea Octans III gyrocompass motion sensor and a Geneq Sx Blue II DGPS ( $\sim 60 \mathrm{~cm}$ precision). A survey was carried out in 2014 in Lake Pasteur on a $4.5 \mathrm{~m}$ inflatable boat using a GeoAcoustics GeoSwath Plus compact $(250 \mathrm{kHz})$ bathy- metric interferometric sonar, the GS + software, a SMC motion sensor and a Hemisphere V101 111 DGPS ( $\sim 60 \mathrm{~cm}$ precision). A repeated survey of the Lake Walker Gravel River delta was carried out in 2016 using a Kongsberg EM 2040 multibeam echosounder (200-400 kHz) coupled with positioning sensor Kongsberg Seapath 330 with GNSS antennas. Sound velocity profiles were obtained with an Odom DigiBAR Pro probe to correct for sound velocity changes in the water column. These mapping techniques allowed a full-bottom coverage below depths of $5 \mathrm{~m}$ of the lakes, except for the southern sector of Lake Pasteur that was not mapped. Raw bathymetric data were processed with the Caris Hips and Sips ${ }^{\circledR} 8.0$ software. The multibeam bathymetric data were processed to generate a 1-m (Lake Pentecôte) and 3-m (lakes Walker and Pasteur) resolution grid digital terrain model (DTM) that was interpreted using the ArcGIS ${ }^{\circledR} 10.1$ and QPS Fledermaus ${ }^{\circledR}$ software. Subbottom data were collected in the three lakes using a Knudsen 3212 Chirp at a frequency of 3.5 and $12 \mathrm{kHz}$ and were processed and visualized with The KingdomSuite ${ }^{\circledR}$, Sonar$\mathrm{Wiz}^{\circledR}$ and QPS Fledermaus ${ }^{\circledR}$ softwares.

\subsection{Coring and sedimentology}

Sediment cores $(\sim 30 \mathrm{~cm}-\sim 8 \mathrm{~m}$ long) were collected using a gravity corer in the three lakes (summer 2014), a percussion corer in Lake Pentecôte and a UWITEC piston coring platform in Lake Walker (winter 2015). The cores were passed through a CT-Scanner at the multidisciplinary laboratory of CT-scan for non-medical use at the Institut National de la Recherche Scientifique - Eau Terre Environnement (INRS-ETE). The resulting high-resolution images allowed the identification of sedimentary structures and facies. X-Ray attenuation, expressed as CT-numbers, is function of density, mineralogy, grain-size and sediment porosity (St-Onge et al., 2007), and was extracted using the ImageJ software. The cores were then opened, described and photographed. Wood fragments as well as a bulk sediment samples were sent to the Radiochronology Laboratory of the Centre d'études nordiques (Université Laval) for pre-treatment and preparation of the sample. The dating itself was performed by accelerator mass spectrometry (AMS) at the Earth System Science Department Keck Carbon Cycle AMS Facility at the University of California at Irvine. The dates obtained were calibrated with Calib 7.0 (Stuiver and Reimer, 1993) using the IntCal13 database (Reimer et al., 2013) and are provided with $2 \sigma$ (Table 1 ). Sedimentation rates were estimated by counting individual lamina couplets in Unit 3 (Fig. 11A), which were inferred to be annually laminated (i.e., varved) due to their appearance and stratigraphic position.

\section{Results}

\subsection{Lake geomorphology}

\subsubsection{Lake Pentecôte}

Lake Pentecôte is divided into three bathymetric zones: the northern sector, the deep central basin and the southern sector (Fig. 2). The northern sector consists of a 50 to $60 \mathrm{~m}$-deep longitudinal central channel surrounded by shallow undisturbed plateaus (Fig. 2A). The undisturbed plateaus are in many cases delimited by long headwall scarps and cut by amphitheater-like mass-movement scarps that are conformably draped with sediments. Most of the large slide scarps have flat bottom planar tabular gliding planes. The presence of locally chaotic surfaces related to depositional lobes, compression ridges and blocky debris on an otherwise relatively flat bottom in the central channel indicates that it is largely filled by mass-movement deposits (MMDs). The lake slopes are eroded by gullies. A few circu- 
Table 1

Description and interpretation of acoustic units, from oldest (U1) to youngest (U4) with lithofacies description of U3 and U4

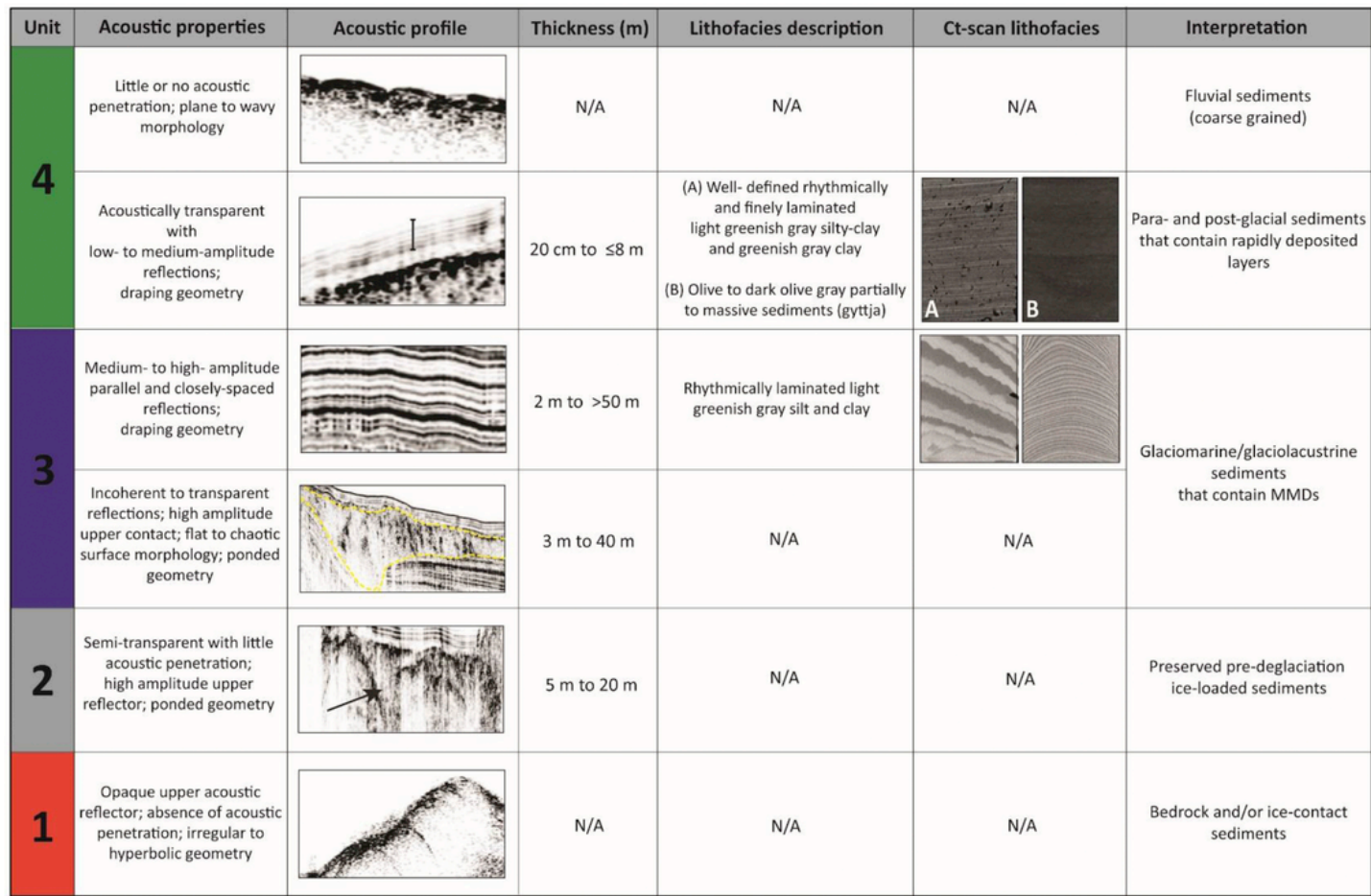

lar cavities are observed on the surface of the northwestern plateaus. Swath bathymetry imagery on the frontal slope of the Pentecôte River delta, at the northern extremity of the lake, shows well-defined crescentic and creeping bedforms (Normandeau et al., 2016a) ending up in a $~ 49$-m-deep circular cavity.

The deep circular basins located in the south-central part of the lake reach depths of $130 \mathrm{~m}$ and are bordered by relatively steep slopes $<60^{\circ}$ (Fig. 2B). These steep slopes are highly affected by slumps and amphitheater-like scarps. Undisturbed plateaus are located in relatively large lake bays. Wide circular cavities of $\sim 200 \mathrm{~m}$ in diameter are observed on the lake-bed of the deep basin.

The southern sector of the lake has a generally chaotic surface morphology with a central narrow trough surrounded by hummocky mounds. A few mass-movement scarps (Fig. 2C) and a thin sediment infill indicated by the lack of acoustic subbottom signal penetration are observed in this sector. The southern sector is separated from the deeper lake basin to the north by a hummocky sill incised by gullies and circular cavities (Fig. 2C; box 1).

\subsubsection{Lake Walker}

The bathymetry of Lake Walker is characterized by a steep-sided and deep chaotic southern basin and a smoother northern basin separated by a central hummocky sill (Fig. 3). The lake has a typical U-shape morphology where the deepest section is often V-shaped. The lake side slopes are $\geq 30^{\circ}$ reaching local angles of $\sim 85^{\circ}$ where the lake shore consists of abrupt rocky cliffs. Fan-deltas are present along the high outer bank where the termini of subaerial valleys and tributaries are connected to the lake. Crescentic and creeping bedforms are observed on the frontal slopes of the Gravel and Schmon River deltas (Normandeau et al., 2016a). These bedforms migrated upslope between 2011 and 2016 (Fig. 4). Well-channelized and moving crescentic bedforms are observed on the Gravel River delta (Figs. 3A and 4) whereas the smaller Schmon River delta is characterized by large regressive mass-movement scarps.

The northern basin of Lake Walker has a smooth morphology and is separated into two sectors by a $\sim 190$-m-deep narrow zone of the lake valley (Fig. 3B; box 2). The northern sector reaches a maximum depth of $260 \mathrm{~m}$ in the circular cavity located upstream of the narrowing zone of the valley. The sidewalls of the northern sector have different levels of well-defined rock benches conformably draped with sediments. The edges of the benches and associated steep slopes are cut by gullies and mass-movement scarps. Gullies and mass-movements are present especially on the slopes of the large narrow western bay (Fig. 3A; box 1). Rare isolated accumulations of large clasts, which appear to be related to subaerial rockfall processes, are present in the northern sector. The southern part of this northern basin is marked by an irregular bench to its western side and attenuated mass-movement morphologies. A minor hummocky bathymetric high is present in the southern part of this basin (Fig. 3B; box 3).

A sill divides the central sector of Lake Walker into two basins (Fig. 3C; box 4). This sector has a chaotic hummocky surface morphology consisting of irregular semi-continuous ridges and multiple mass-movements and depressions. The southern basin of Lake Walker reaches a maximum depth of $271 \mathrm{~m}$ (i.e., $156 \mathrm{~m}$ below sea level), making it one of the deepest lakes reported so far in eastern Canada. The basin shows on its south central section a well-defined arc-shaped ridge (Fig. 3D; box 5; MB). The basin has a highly chaotic lake floor mainly consisting of a hummocky morphology, creeping slopes, gullies and mass-movements. (Fig. 3C and D). The southern extremity of the basin is characterized by a hummocky bathymetric high and the narrowing of the lake valley (Fig. 3D; box 6).

\subsubsection{Lake Pasteur}

The northern sector of Lake Pasteur has two deep semi-circular basins with steep sidewalls $\left(<60^{\circ}\right)$ separated by a 45 -m-deep bathy- 


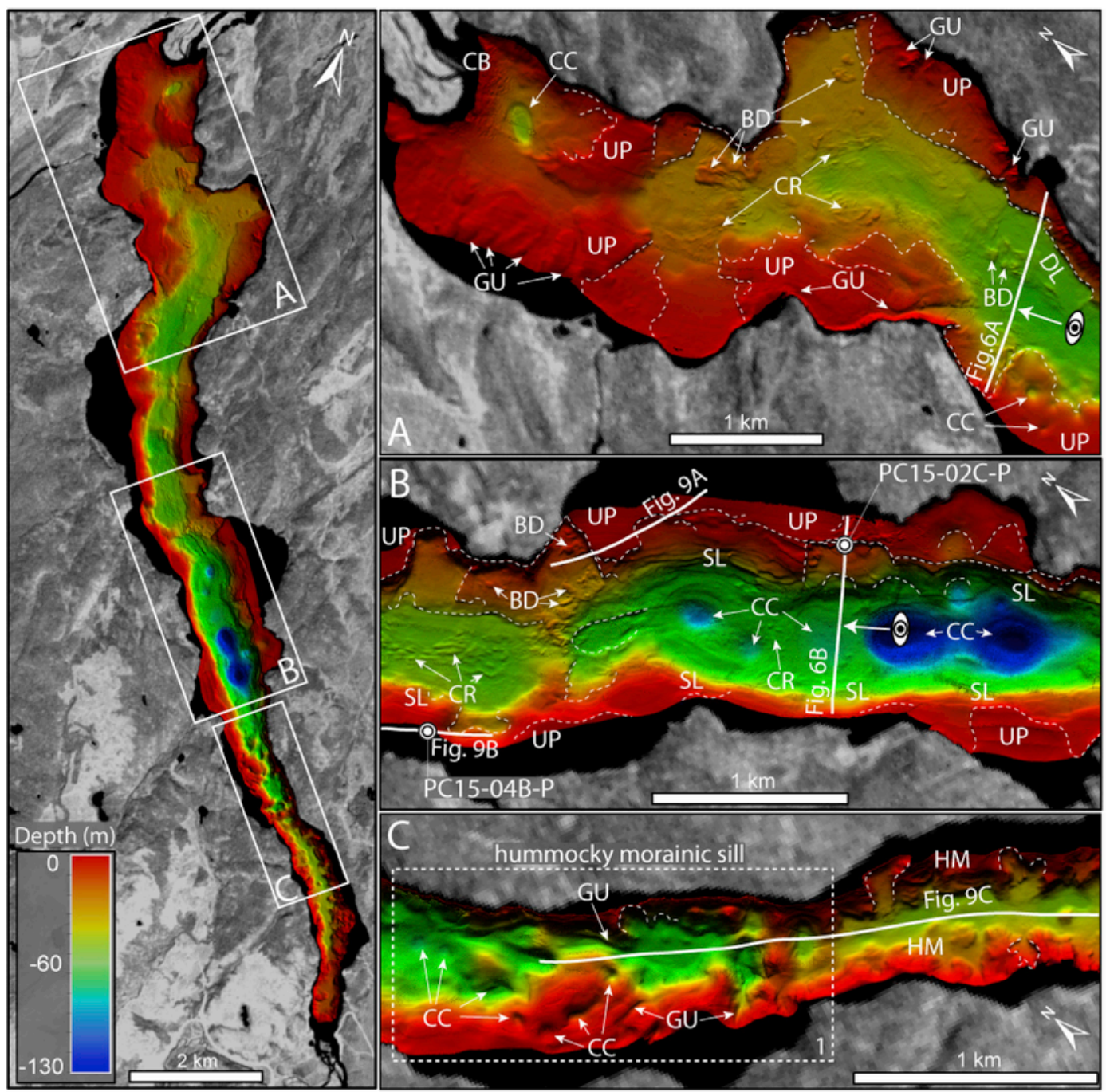

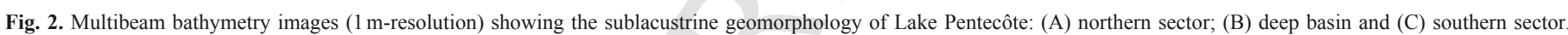

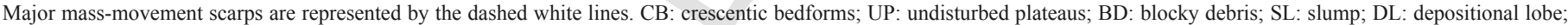
CR: compression ridges; HM: hummocky mound; CC: circular-cavity; GU: gully.

metric high (Fig. 5). Crescentic bedforms are observed at the northern extremity of the lake on the sublacustrine delta of the Pasteur River (Normandeau et al., 2016a). The deepest basin is located in the central part of the mapped area and reaches $71 \mathrm{~m}$ in depth, whereas a 60-m-deep basin is observed at the northern extremity of the lake (Fig. $5 \mathrm{~A})$. The slopes bordering the lake are incised by gullies and show a few fan-deltas that extend along the basin slope, where slide scars, depositional lobes and debris flows are also observed on the swath bathymetry imagery (Figs. 5 and 6C). The southern sector of the mapped area is characterized by gentle slopes and shallow depths reaching $36 \mathrm{~m}$, forming a relatively smooth lake floor with draping sedimentation (Fig. 5B). South of this mapped sector, the only available data are subbottom profiles that show a relatively flat bottom and mass-movement morphology. Aerial photographs (Fig. 5; box 1,2) show the presence of bathymetric highs.

\subsection{Acoustic stratigraphy and associated lithofacies}

The acoustic subbottom data allowed the identification of four acoustic stratigraphic units in lakes Pentecôte, Walker and Pasteur. These units have been interpreted on the basis of their acoustic facies properties and geometries as well as on previous acoustic stratigraphy studies in Québec (Shilts and Clague, 1992; Shilts et al., 1992; Ouellet, 1997; Turgeon et al., 2003; Normandeau et al., 2013, 2016a; Nutz et al., 2014; Lajeunesse et al., 2017; Normandeau et al., 2017). These units are reported following this classification: Unit 1 (U1), acoustic basement; Unit 2 (U2), ice-loaded sediments; Unit 3 (U3), glacimarine and/or glaciolacustrine sediments; Unit 4 (U4), para- and post-glacial sediments (Table 1). The acoustic stratigraphy data allow an inter-lake correlation of acoustic stratigraphy units. However, these units are not synchronous, as ice retreat in the three lakes did not occur at the same time. Acoustic units 3 and 4 have been cored, allowing them to be associated with their sedimentary facies.

\subsubsection{Unit 1 (U1): acoustic basement}

$\mathrm{U} 1$ is the lowermost unit observed on the subbottom profiles. It is observed where steep slopes prevent the accumulation of a thick sediment drape and near the lake shores, on the underlying plateaus of Lake Pentecôte (Fig. 6A), the benches of Lake Walker (Fig. 7) and the isolated mounds of Lake Pasteur (Fig. 8C). U1 has a hummocky morphology clearly visible in the southern sector of Lake Pentecôte (Fig. 9C) and in the southern basin of Lake Walker (Fig. 10D). This 

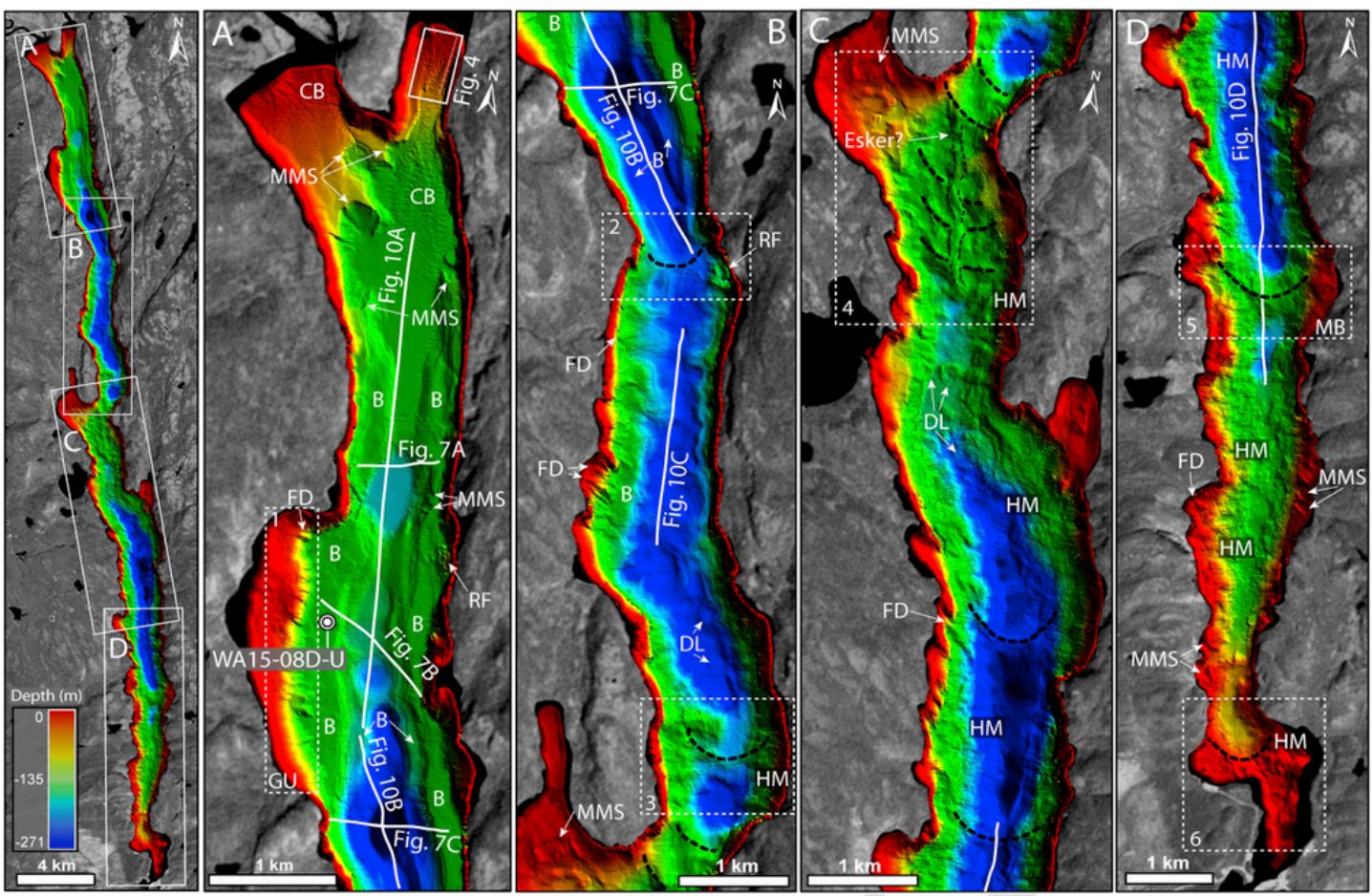

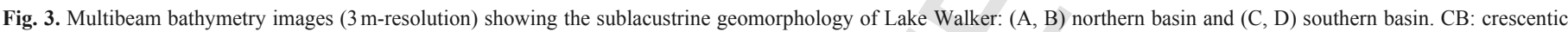

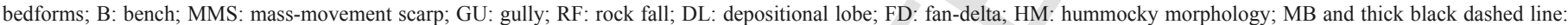
morainal bank

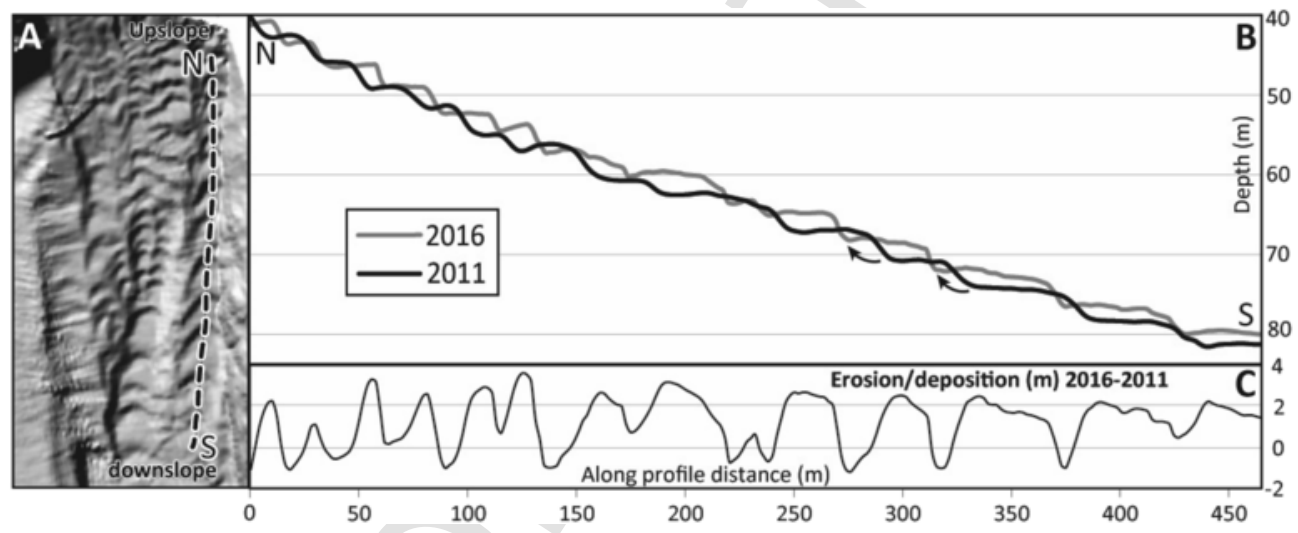

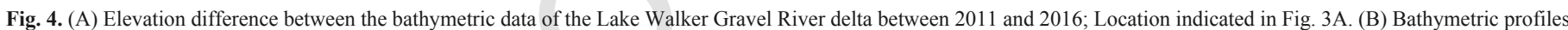

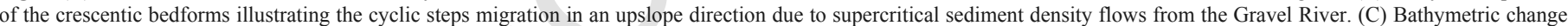
(erosion/deposition) along the profile.

hummocky to chaotic morphology is interpreted as either bedrock or ice-contact deposits (till) covered by a thin drape of Late-Quaternary sediments (U3-U4). The acoustic signal did not allow reaching Unit 1 in the deeper and northern areas of the lakes where sandy deltaic sediments are present, and where sediments exceed $40 \mathrm{~m}$ in thickness. The subbottom data of the three lakes allowed the observation of sediment drapes over incised deep lower V-shaped bedrock valleys (Fig. $6 \mathrm{~A}$ and B, 7, 9C, 10C), previously interpreted by Lajeunesse (2014) as preglacial fluvial bedrock valleys and channels. These V-shaped valleys follow the longitudinal axis of the lakes and contain $>40 \mathrm{~m}$ of sediments in some sectors and up to $60 \mathrm{~m}$ in Lake Pentecôte.

\subsubsection{Unit 2 (U2): ice-loaded sediments}

U2 has a basin-fill geometry and is observed only in deeper portions of the southern basin of the lakes Pentecôte (Fig. 9C) and Walker (Fig. 10C). In all cases, it is conformably draped with U3 sediments. U2 has a sharp upper contact that could be of erosive origin and has been interpreted as ice-loaded pre-Late-Wisconsinan sediment preserved from the last glacial episode (e.g., Syvitski and Praeg, 1989; Shilts and Clague, 1992; Shilts et al., 1992; Normandeau et al., 2013, 2017). This unit is not observed on acoustic subbottom profiles in the northern sectors of the lake, probably due to the lack of acoustic penetration in the overlying units in these sectors (U3 and U4). It is possible that the last glaciation did not erode the deep V-shaped inner basin of the lakes, allowing the preservation of 

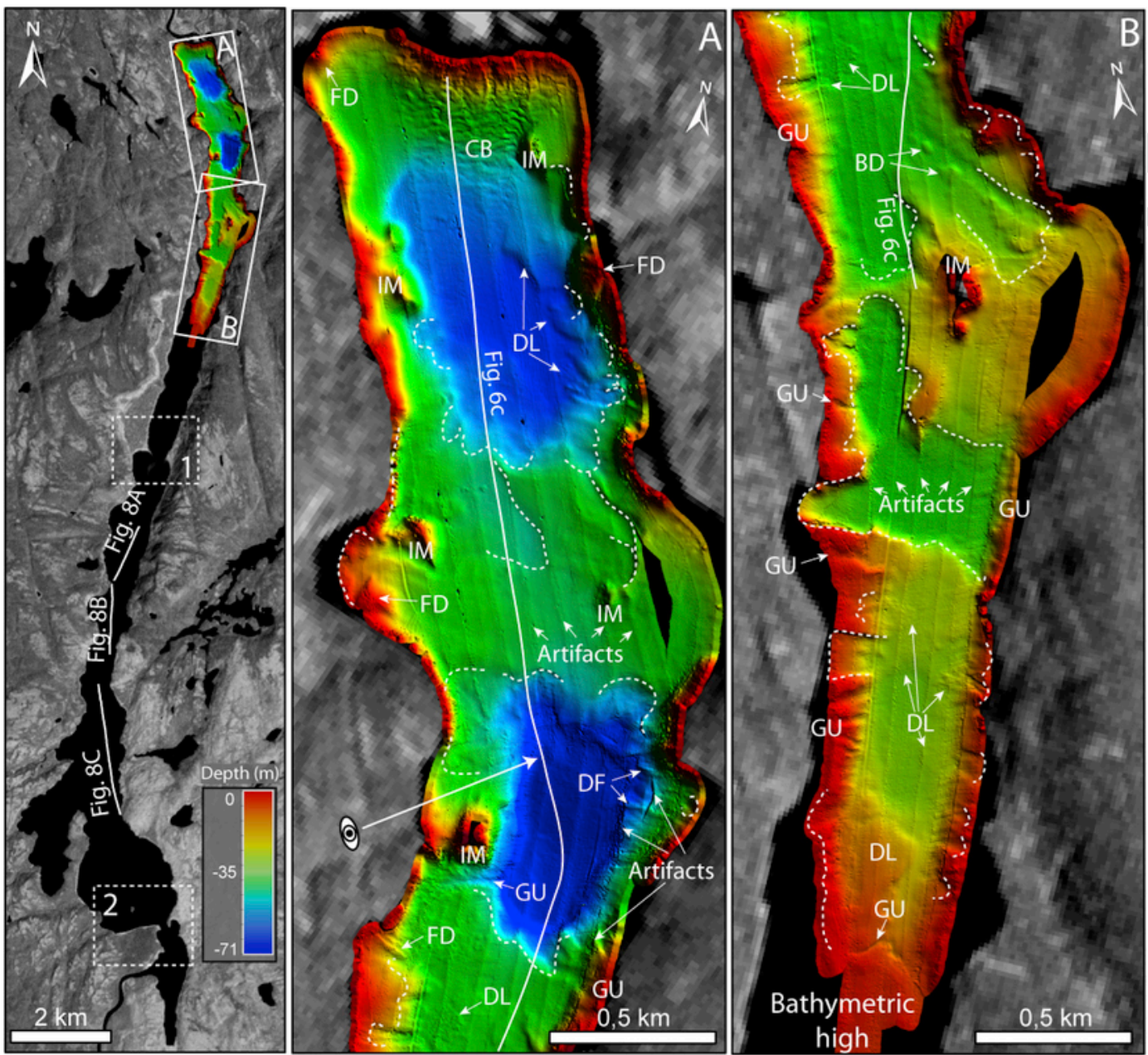

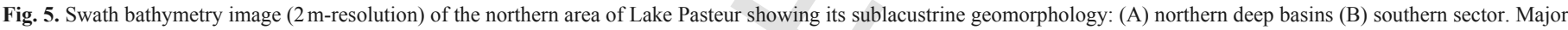

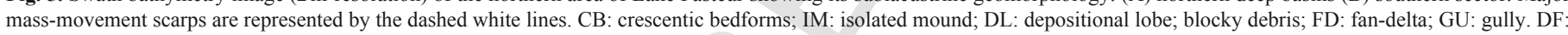
debris flow.

older (pre-Late-Wisconsinan?) sediments. However, its origin and age of this unit still need to be confirmed.

\subsubsection{Unit 3 (U3): glaciomarine and/or glaciolacustrine sediments}

U3 has a smooth surface and can reach a thickness of $\geq 50 \mathrm{~m}$ in many undisturbed sectors of the lakes (e.g. Fig. 8; 9A; 10C), but can reach $>80$-thick in Lake Pentecôte. U3 shows typical acoustic characteristics of high amplitude parallel reflections observed in other formerly glaciated lake basins (Mullins and Hinchey, 1989; Eyles et al., 1990, 1991; Shilts and Clague, 1992; Ouellet, 1997; Turgeon et al., 2003; Lajeunesse et al., 2008, 2017; Doughty et al., 2013; Evans, 2013; Doughty et al., 2014). The base of U3 is interpreted as glaciomarine sediments deposited during the Goldthwait Sea transgression, changing into glaciolacustrine sediments due to lake isolation induced by glacio-isostatic rebound. U3 deposits are much thinner in the southern sector of Lake Pentecôte $(\sim 2-4 \mathrm{~m})$ (Fig. 9C) and the southern basin of Lake Walker ( $\sim 5 \mathrm{~m})$ (Fig. 10D). In these areas, the acoustic facies of $\mathrm{U} 3$ is in some cases characterized by a series of chaotic and diffuse reflectors (e.g. Fig. 9C; left side).

$\mathrm{U} 3$ has been sampled in the cores collected on a 14-m-deep plateau (PC15-04B-P; Figs. 9C and 11A), on the flank of a mass-movement scarp (PC15-02C-P; Figs. 6B and 11B) in Lake Pentecôte, and on a bench in the northern sector of Lake Walker (WA15-08D-U; Figs. $7 \mathrm{~B}$ and $11 \mathrm{C}$ ). Its lithology consists of rhythmically laminated silt and clay. Mean CT-number values are $>2000 \pm 107$ HU, reflecting the high-density nature of this unit; however, the central part of the density profile shows a clear rhythmic alternation. The upper section of U3 consists of laminated silty-clay (possibly varved?). Assuming the laminations are varves, a total of 99 couplets were counted in an undisturbed slightly bounded section of the core (PC15-04B-P; Fig. 11A) measuring $63 \mathrm{~cm}$, suggesting relatively high sedimentation rates, with $6.3 \mathrm{~mm} \mathrm{a}^{-1}$. A lower section of U3 visible in core PC15-02C-P (Fig. 11C) shows that some laminae reach $2 \mathrm{~cm}$ in thickness, suggesting a higher sedimentation rate. The presence of deformation is probably due to disturbance during the percussion coring process.

$\mathrm{U} 3$ as a whole depicts acoustic signature of mass-movement scarps, slumps, gravitational faults (Fig. 6A and B, 9A) and MMDs (Figs. 6-10). Glide planes of the MMDs often appear on the subbottom profiles as thick transparent or incoherent layers within U3 (Fig. 6B). Based on the stratigraphic position, MMDs are buried under 4-8 $\mathrm{m}$ of sediments of units 3 and 4 . The acoustic properties are similar to those of acoustic units interpreted as MMDs in other lakes of eastern Canada (Doughty et al., 2013, 2014; Normandeau et al., 2013; Lajeunesse et al., 2017; Normandeau et al., 2016b, 2017). 


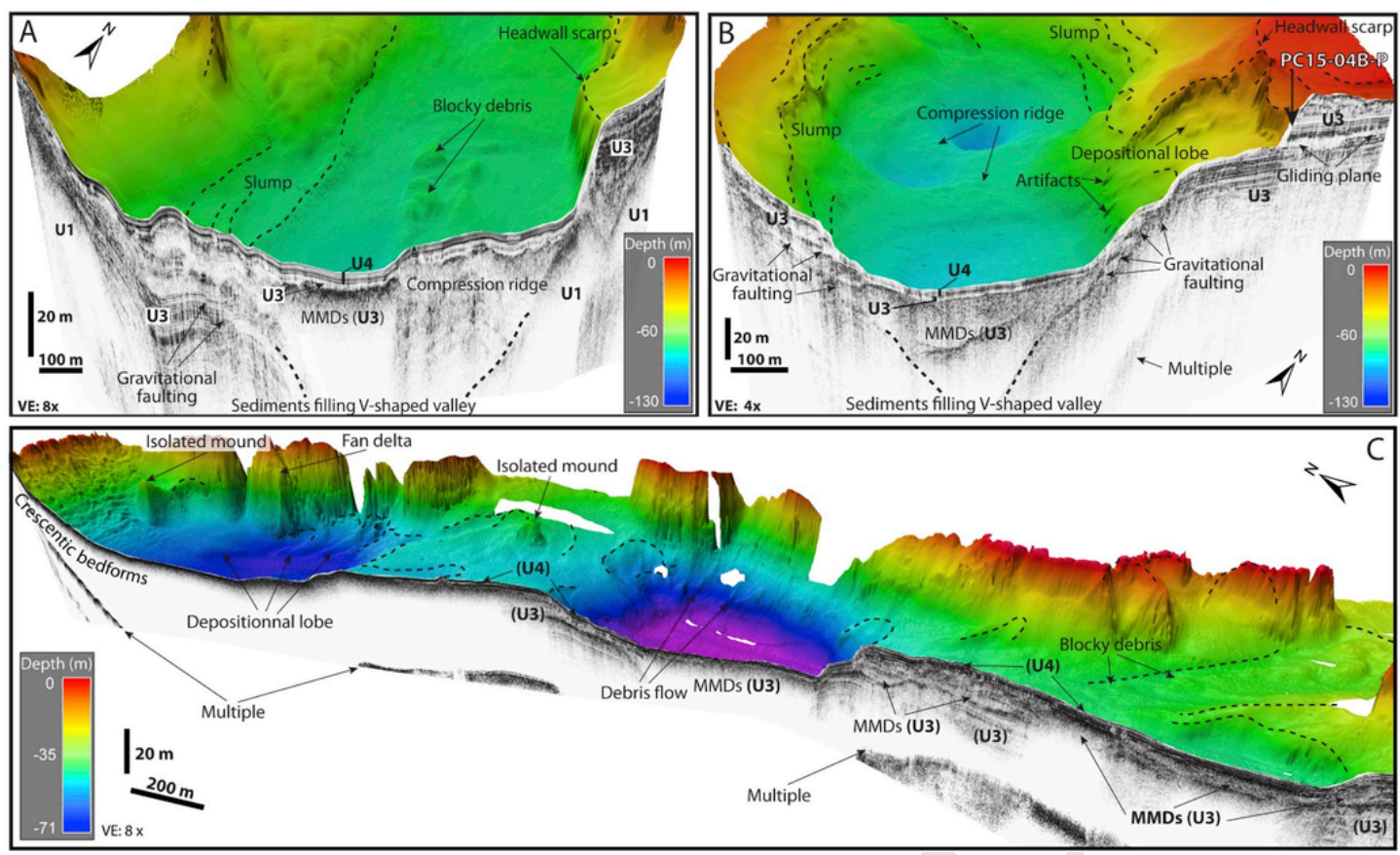

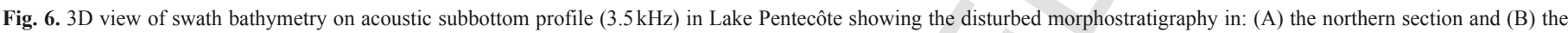

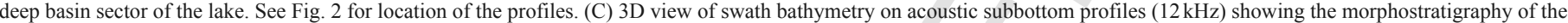
northern section of the Lake Pasteur. See Fig. 5 for location of the profiles. Slump and mass-movement scarps are represented by the black dashed line.

\subsubsection{Unit 4 (U4): para- and post-glacial sediments}

$\mathrm{U} 4$ is the uppermost acoustic unit and is present over the entire bottom of the three lakes (Figs. 6-10). U4 has a slightly different acoustic signature compared to $\mathrm{U} 3$, which is characterized by a change in the amplitude of the reflections at the transition between the two units. U4 is characterized by faint to medium amplitude parallel reflections in its lower part and a semi-transparent acoustic facies in its upper part; these two types of acoustic facies generally correspond to paraglacial sediments and postglacial sediments, respectively (e.g., Normandeau et al., 2017). These two sedimentary environments are grouped here within the same unit due to the presence of higher amplitude reflections in some parts of the unit, which could be associated with intercalated turbidites in laminated sequences observed down U4 in cores PC15-04B-P and WA15-08D-U (Fig. 11). Therefore, these two environments cannot always be differentiated in the studied lakes, especially when its thickness is $<1 \mathrm{~m}$ in some sectors. U4 is thicker in deep basins $(\leq 8 \mathrm{~m})$ and contains medium to high amplitude parallel reflections. Its upper section shows evidence of gravity processes that may have eroded the uppermost sections.

A zone where the acoustic signal does not penetrate the lake floor is observed at the top of the subbottom profiles in the northern extremity of the three lakes, near the main river mouths (Figs. 6C and 10A), and where secondary tributaries connect with the lakes. The delta and fan deposit areas are marked by a high amplitude reflection at the lakebed surface with acoustic attenuation down the unit due to the presence of coarser sediments, probably sands from turbidity currents associated with delta slopes (Normandeau et al., 2016a). The distal portions of the deltaic slopes are draped by a thin transparent acoustic layer associated with U4.

U4 sediments have been sampled in all the cores collected in the three lakes. Its lithology consists of rhythmically to partially laminated and massive postglacial sediments (Nzekwe et al., in press) with irregularly spaced intervals of Rapidly Deposited Layers (RDLs, St-Onge et al., 2012) (Fig. 11A, C). CT-number values are $1500 \mathrm{HU}$ and reach $\sim 2000 \mathrm{HU}$ where RDLs occur. U4 shows a slight decreasing trend in CT-number values down to $\sim 1000 \mathrm{HU}$ toward the top of the unit, most probably due to decreasing compaction. The presence of sporadically concave downward laminae, deformation and discontinuities may have been caused by the coring operations or mass-movement processes.

In Lake Pentecôte, U4 was sampled in cores PC15-04B-P (Figs. 9B and 11A). Bulk sediment collected at $101 \mathrm{~cm}$, which marks the transition between units 3 and 4, provides an age for the base of the unit at $7240 \pm 25 \mathrm{yr}$ BP $(8000-8160 \mathrm{cal} \mathrm{BP}$; UCIAMS-162978; Fig. 11A; Table 2$)$. U4 has been entirely sampled $(\sim 650 \mathrm{~cm})$ on the cored bench in the northern sector of Lake Walker (core WA15-08D-U, 140-m deep; Figs. 7B and 11A). A dated wood fragment collected at a depth of $647 \mathrm{~cm}$ near the transition between units 3 and 4 provides an age of $7060 \pm 25 \mathrm{yr}$ BP (7845-7950 cal BP; UCIAMS-161066; Fig. 11A; Table 2) for the base of U4. Well-defined rhythmically laminated sediments are present in the lower part of U4 in Lake Pentecôte and semi-continuously in the whole U4 sequence in Lake Walker. In its upper part U4 is characterized by faintly laminated to massive organic-rich postglacial sediments.

\section{Discussion: sedimentary environments}

\subsection{Proglacial environment}

According to the Occhietti et al. (2011) deglaciation model, the retreat of the LIS margin over the three lakes and their watersheds was not synchronous despite their proximity, but was rather influenced by their respective elevation. Deglaciation is therefore described separately for the three lakes; we refine this model based on new results from the lakes. 

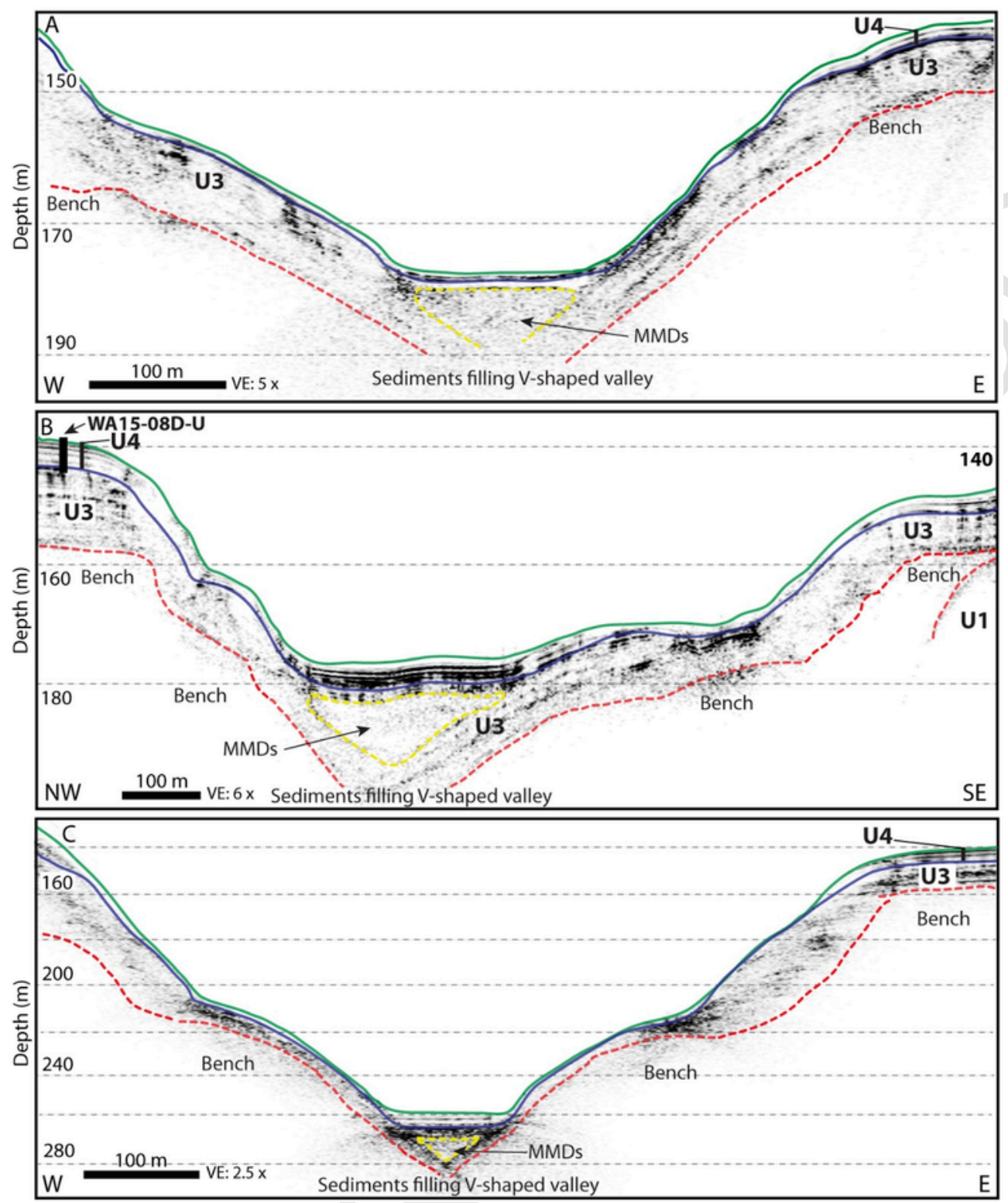

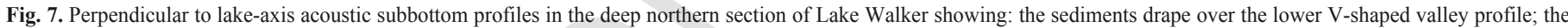

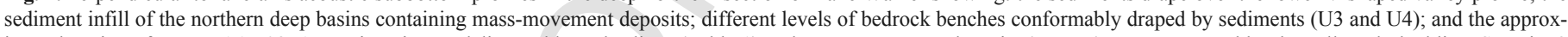

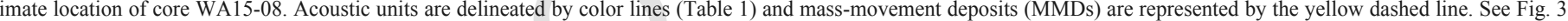
for location of the profiles. (For interpretation of the references to color in this figure legend, the reader is referred to the Web version of this article.)

\subsubsection{Lake Pentecôte}

Lake Pentecôte was the first to be deglaciated and to be inundated by the Goldthwait Sea. By $\sim 11.5$ ka cal BP (Occhietti et al., 2011), the retreating LIS margin reached a topographic high (i.e., knickpoint step) at the outlet of the Lake Pentecôte valley that led to the deposition of an ice-contact fan (Figs. 12B and 13B). The ice retreat over the lake began with the abandonment of the fan at an elevation slightly below marine limit (Figs. 12C and 13C). Regardless of the differential glacio-isostatic flexure, which could reach $1 \mathrm{~m} \mathrm{~km}^{-1}$ (Shaw et al., 2002), the elevation of the lake basin indicates that it has been invaded by the Goldthwait Sea. The presence of the acoustic basement (U1) forming hummocky topography in the southern sector of Lake Pentecôte (Fig. 9C) suggests a first phase of stabilization on this sill in shallow marine water. The hummocky morainic sill ob- served downstream of the deep lake basin (Fig. 2; box 1) located near terrestrial morainic ridges (Fig. 1C) indicates the occurrence of a short-term stabilization of the ice margin at this location. The following retreat of the LIS margin might have been accelerated by ice collapse and iceberg calving in deeper waters (e.g., Mangerud et al., 2013), thus allowing the deep basin to receive and store sediments instead of the southern sector of the lake.

Lake Pentecôte was isolated from the sea due to the emergence of its outlet ice-contact fan during glacio-isostatic rebound, which led to the formation of a glaciolacustrine basin as the LIS margin was still located in the watershed (Figs. 12E and 13D). Sedimentation in the deep lake basin was dominated by the rapid deposition of glacigenic sediment in an ice proximal to distal setting, leading to the deposition of glaciomarine and/or glaciolacustrine sediments (U3) reaching $>80 \mathrm{~m}$ in thickness in the undisturbed parts of the lake. The formation 

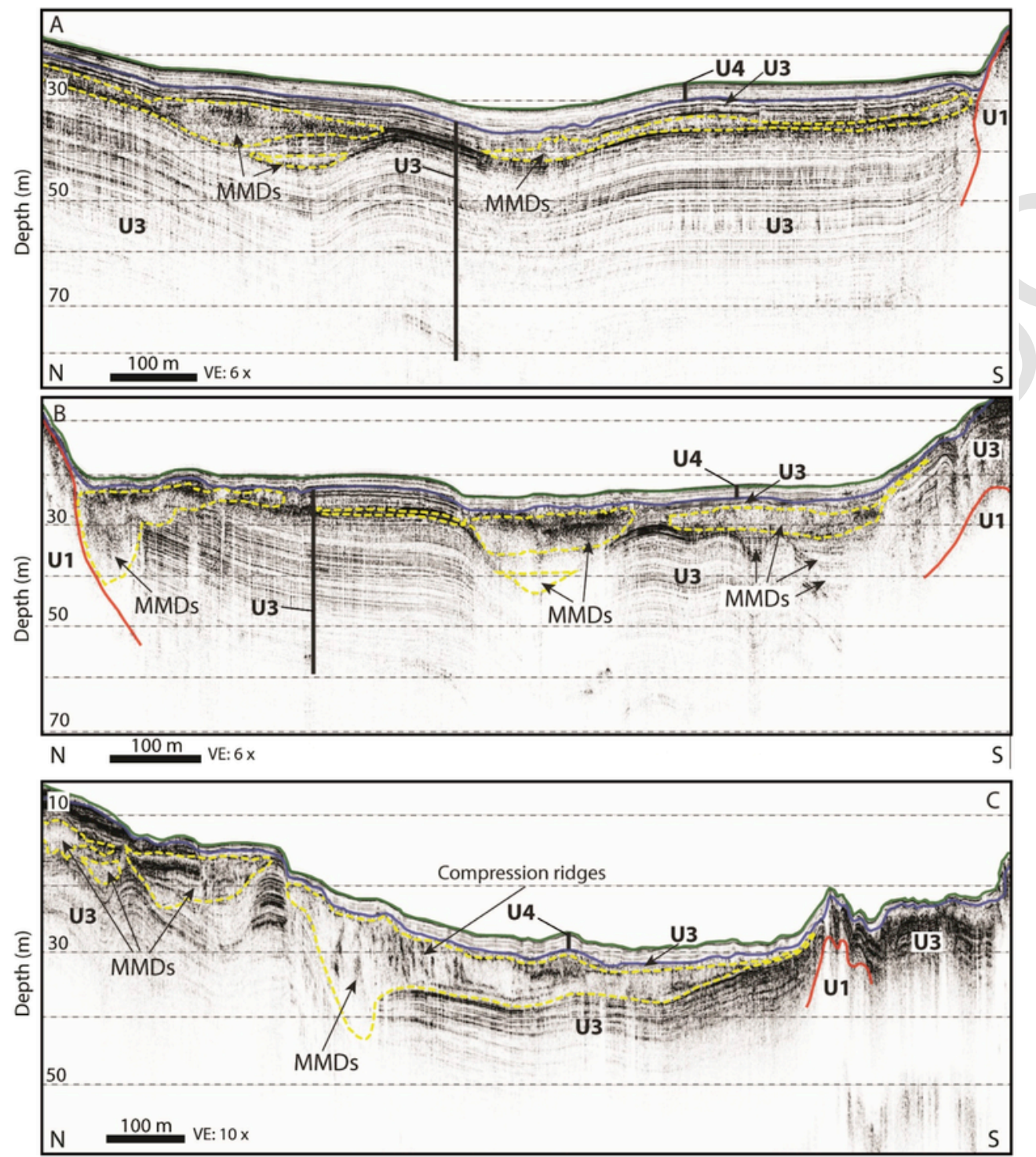

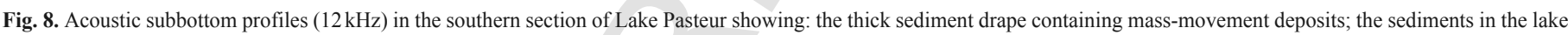

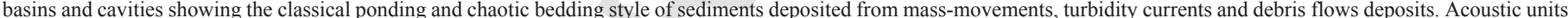

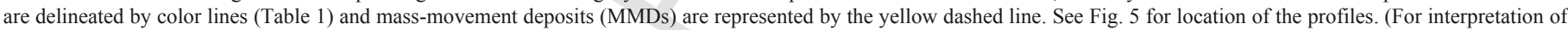
the references to color in this figure legend, the reader is referred to the Web version of this article.)

of the deep circular cavities, gravitational faults and external terraces observed in this lake (Figs. 2 and 6A, B, 9A) has been previously interpreted as the result of in-situ melting of buried ice masses in former glacial lakes (Eyles et al., 1991; Turgeon et al., 2003; Doughty et al., 2014). It is possible that local masses of dead ice were buried during the fast retreat of the proximal ice-contact deposition and remained along the basin floor due to the input of large volumes of meltwater sediments in Lake Pentecôte. It is questionable, however, how such large ice masses would not become buoyant in the lake basin rather than remain on the lake bottom during their burial by sediments. Alternatively, these circular cavities could have been formed either by differential sediment filling and draping over the irregular lake bottom morphology due to the presence of interlocking spurs of preglacial fluvial bedrock channels (Lajeunesse, 2014) or by strong channelized meltwater flows that scoured these depressions.

Rhythmically laminated silts and clays (U3) sampled in Lake Pentecôte correspond to sedimentation controlled by glacial-melt runoff (i.e., ice-distal varves?) (Powell, 1983; Ó Cofaigh and Dowdeswell, 2001; Guyard et al., 2011, 2014; Ridge et al., 2012; Boes, 2014). The lower thick laminations (PC15-04B-P; Fig. 11B) reflect a depositional environment characterized by high glacigenic suspended loads (i.e., plumes) in an ice-proximal regime (e.g., Figs. 12C and 13C). The thin upper lamination reveals a decrease in sedimentation input caused by the increasing distance of the LIS margin in the watershed. When the ice margin was retreating $>30 \mathrm{~km}$ upstream of the lake valley (Figs. 12C and 13D), the LIS margin might have become disconnected with the Pentecôte glaciolacustrine basin, leading to sediment supply essentially controlled by a glaciofluvial outwash plain confined in the axis of the valley with a delta that prograded into the lake. The accumulation rates of $4 \mathrm{~cm} \mathrm{a}^{-1}$ (inferred from the $4 \mathrm{~cm}$ laminae couplet thickness) to $0.63 \mathrm{~cm} \mathrm{a}^{-1}$ are similar to those observed in present-day glacial lakes in the Canadian Cordillera and Patagonia (Desloges and Gilbert, 1995, 1998; Gilbert and Desloges, 2012; Van Daele et al., 2016), depending on the influence and distance of glacial 

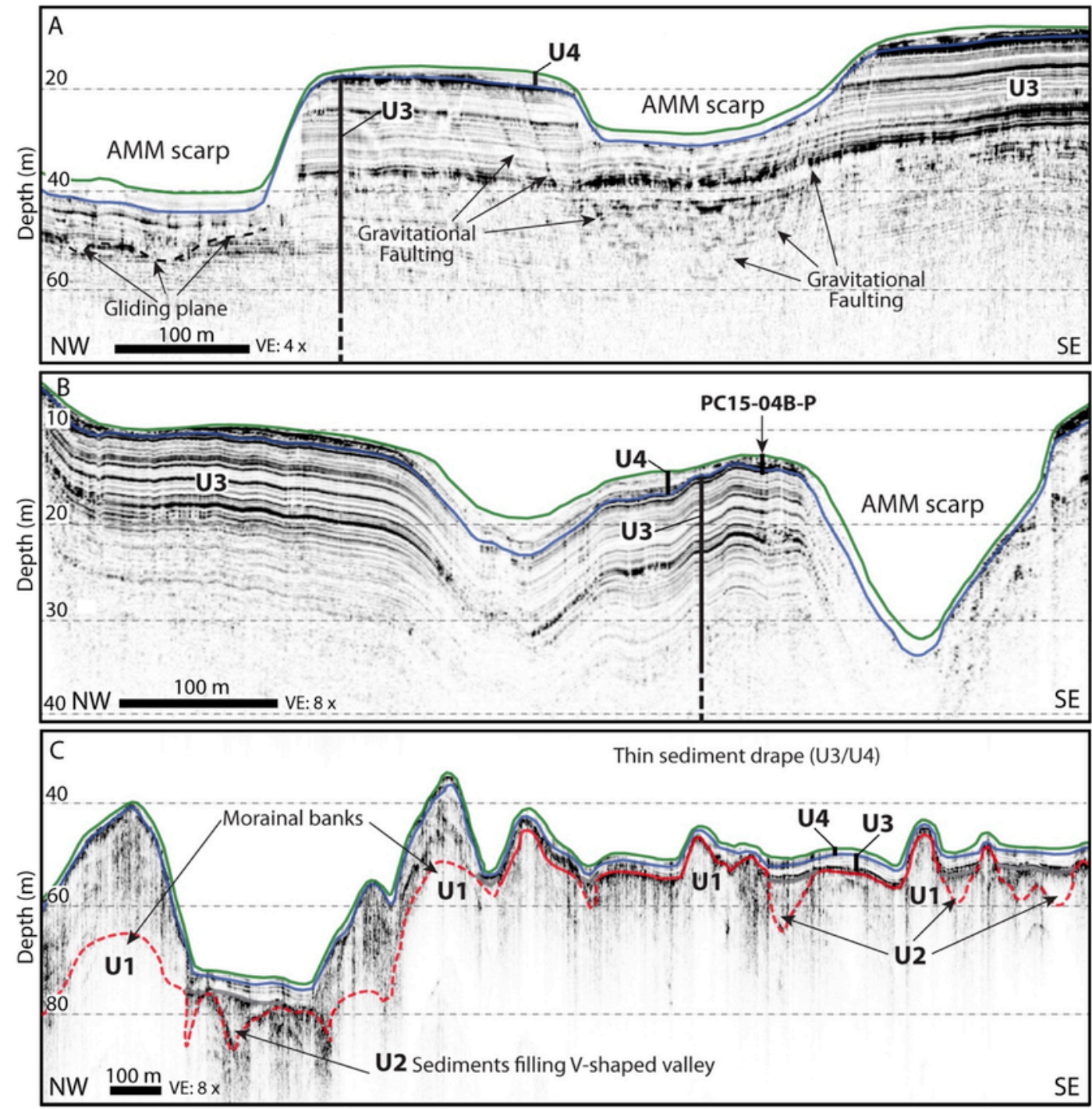

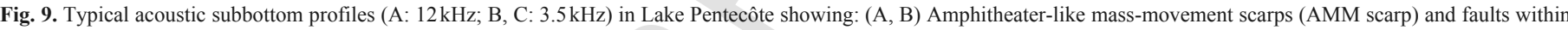

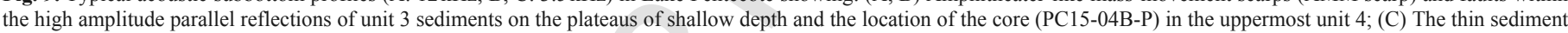

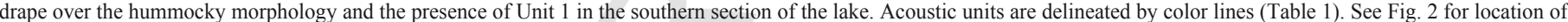
the profiles. (For interpretation of the references to color in this figure legend, the reader is referred to the Web version of this article.)

processes in watersheds. The apparent undisturbed sharp transition between U3 and the upper U4 postglacial sediments is interpreted to correspond to the retreat of the LIS margin from the Lake Pentecôte watershed (Figs. 12F and 13E) (e.g., Normandeau et al., 2017; Dietrich et al., 2017b) dated at $<8000-8160 \mathrm{cal}$ BP $(7240 \pm 25 \mathrm{yr}$ BP; UCIAMS-162978; Fig. 12A, Table 2). This age is consistent with the 8.2 ka cal BP LIS margin position suggested by Occhietti et al. (2011) near the northern limit of the watershed.

\subsubsection{Lake Walker}

Located at $115 \mathrm{~m}$ asl, $30 \mathrm{~km}$ north of the modern coastline, Lake Walker was deglaciated later than Lake Pentecôte. As the Goldthwait Sea reached its maximum elevation $(130 \mathrm{~m}$ asl $)$ in the region at $\sim 10.8$ ka cal BP (Occhietti et al., 2011), the LIS margin was reaching a stabilisation phase $\sim 10 \mathrm{~km}$ south of the lake to deposit an ice-contact fan (Dredge, 1983). This paleogeographical context probably did not allow a sufficient time period for the Goldthwait Sea waters to invade the lake basin (Fig. 12C). During deglaciation of the area south of the lake, the low structural connectivity of the lake valley with the open coast (Goldthwait Sea) could have prevented significant contact with marine waters and reduced the rate of ice retreat (Fig. 12C). Between 10.8 and $10 \mathrm{ka}$ cal BP, a second stabilization phase led to the deposition of the outlet ice-contact fan located at the southern end of the lake (12D), which was constructed at the same elevation $(115-130 \mathrm{~m}$ asl today) as marine limit. After a few hundred years of glacio-isostatic rebound, the elevation of this ice-contact fan and the presence of ice could also have prevented the occupation of the lake by the Golthwait Sea (Fig. 14B).

The presence of the acoustic basement (U1) forming hummocky topography covered by thin sediment layer (U3 and U4) in the southern basin of the lake suggest the persistence of an ice margin in the basin that could have delayed or prevented an early deposition of glaciomarine and/or glaciolacustrine laminated sediments. The well-defined morainal banks observed south of the lake (Fig. 3; box 2) suggest the presence of an ice tongue terminus during deglaciation that was grounded to the lake bottom during a short-lived stabiliza- 

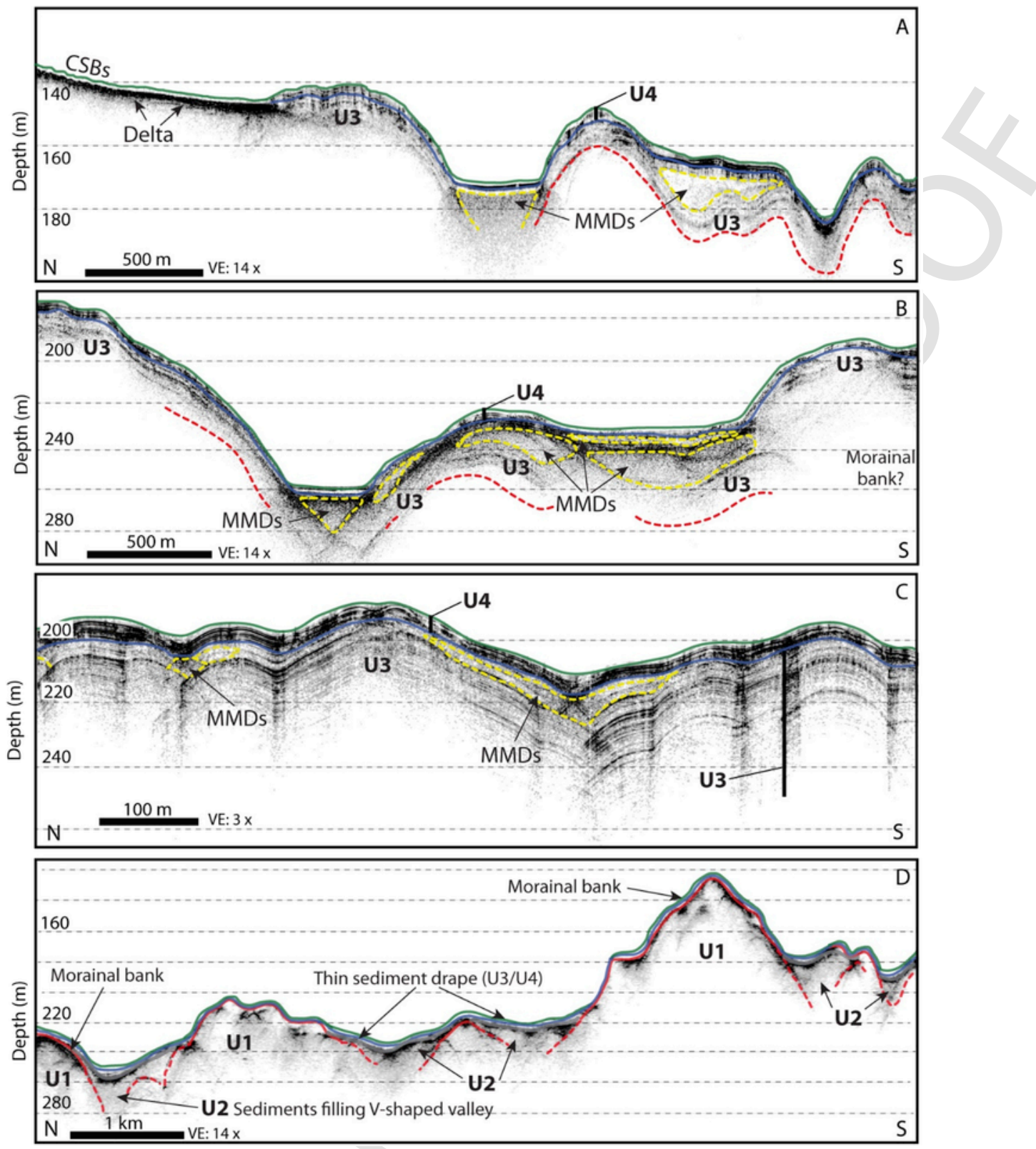

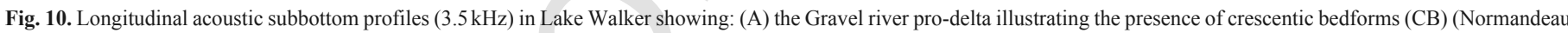

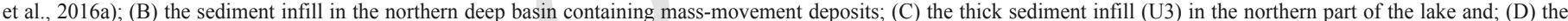

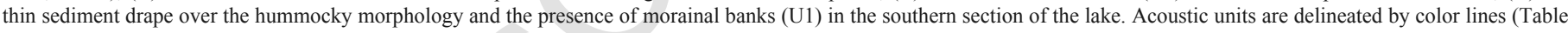

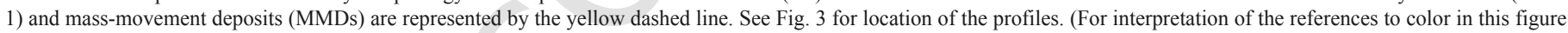
legend, the reader is referred to the Web version of this article.)

tion (e.g., Geirsdóttir et al., 2008). Subsequently, the retreat of the LIS margin in the deep southern basin probably accelerated rapidly, preventing sediment infilling the basins and rather depositing a thin sediment drape. Bathymetric highs observed along the bottom of Lake Walker indicate a deglaciation of the entire basin punctuated by short-term stabilizations (Figs. 3 and 14B, C).

The LIS margin grounded on the topographic high (i.e., knickpoint step) on the sill in the central part of the lake, which led to the construction of an esker-like ridge that is cut perpendicularly by closely spaced morainic ridges (Fig. 3; box 3) (e.g., Brennand, 2000). At that time, relative sea level had fallen quickly making the presence of marine waters unlikely. The Lake Walker basin was isolated from the sea as it was still widely occupied by ice (Figs. 12D and 14C), leading to the formation of a glaciolacustrine basin. After the retreat of the ice margin from the central sill (Figs. 12E and 14D), the northern basin acted as a sediment trap (Fig. 10D), leading to the deposition of $\sim 50 \mathrm{~m}$ thick rhythmically laminated sediment (U3) (Fig. 10C) delivered by glacial meltwaters during deglaciation of the Lake Walker watershed (Fig. 12E and F, 14D). Rhythmically laminated silts and clays (U3; Fig. 11C) sampled in the northern basin of Lake Walker are very similar; they are observed at the same stratigraphic level as those observed in Lake Pentecôte, suggesting a common origin. The transition between the lower U3 and the upper $(\sim 6,5 \mathrm{~m})$ finely laminated sediments sequence (U4) is also interpreted to correspond to the retreat of the ice margin from the Lake Walker watershed (Figs. 12G and 14E), dated at $<7845-7950$ cal BP $(7060 \pm 25 \mathrm{yr}$ 

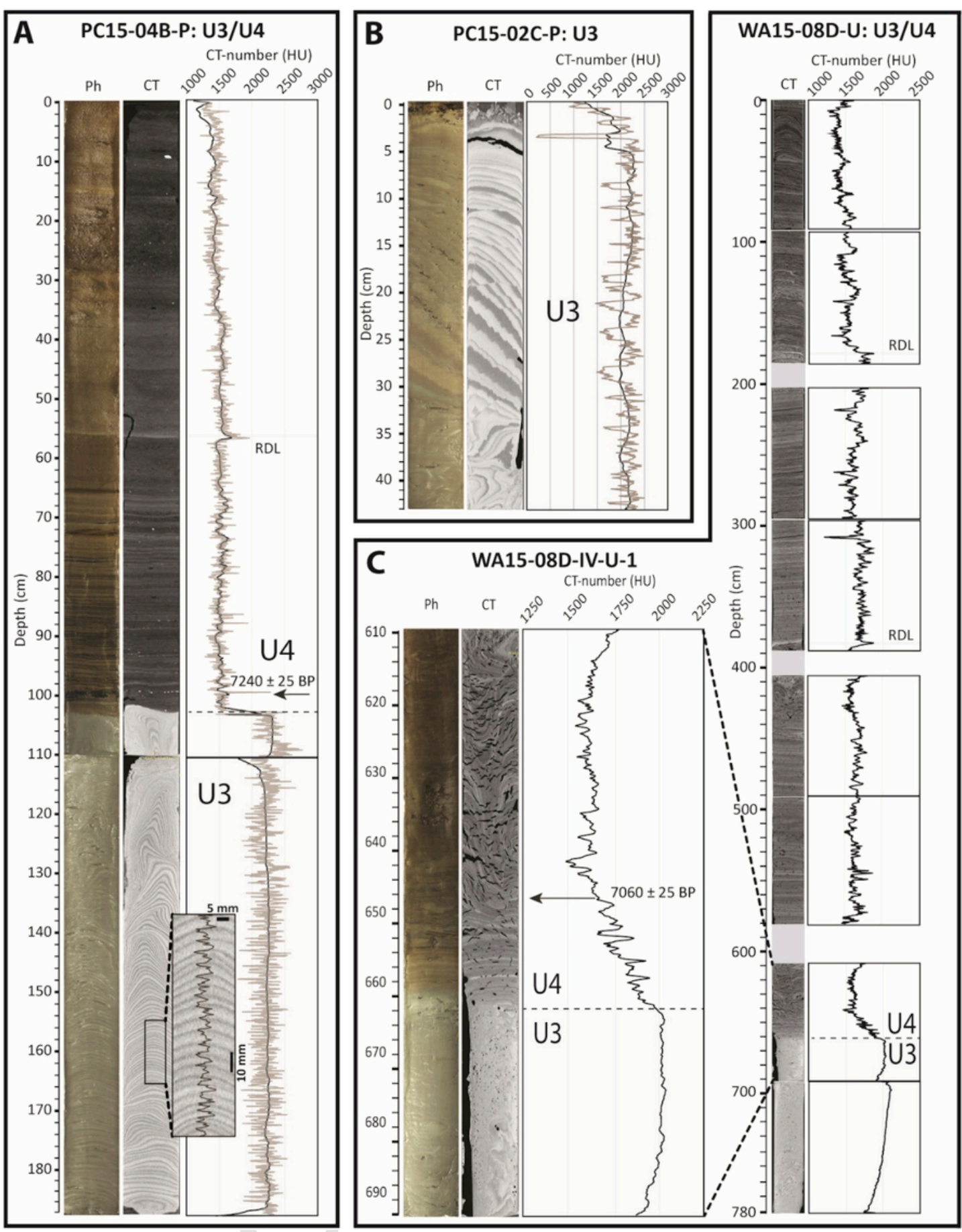

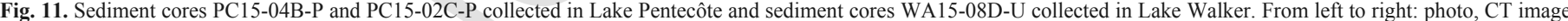

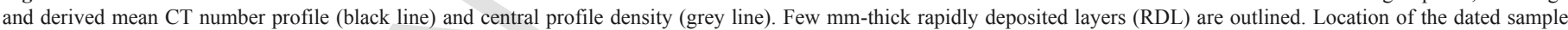
(AMS 14C) that marks the transition between units 3 and 4 is indicated by a black arrow. See text for details and Figs. 2, 3 and 6B, 7B, 9B for core location.

BP; UCIAMS-161066; Fig. 11C; Table 2). The age obtained for the complete deglaciation of the Lake Walker watershed $(<7845-7950 \mathrm{cal}$ BP; Table 2) is slightly younger than the age for deglaciation of the Lake Pentecôte watershed ( $<8000-8160$ cal BP; Fig. 11A; Table 2); this observation is consistent with its larger northward extent and its connection to the glacial systems for a longer time. This age allows refining the paleogeography of the LIS retreat between 8.2 and $7.5 \mathrm{ka}$ cal BP (Occhietti et al., 2011) in the study area.

\subsubsection{Lake Pasteur}

By $10.8 \mathrm{ka}$ cal BP, the retreating LIS margin reached the outlet area of the Lake Pasteur valley where it deposited a subaqueous ice-contact fan (Dredge, 1983). Ice retreat over the lake occurred between 10.8 and $10 \mathrm{ka}$ cal BP (Occhietti et al., 2011). Similarly to Lake Pentecôte, the elevation of the Lake Pasteur outlet ice-contact fan below marine limit suggests that it was immediately invaded by 
Table 2

AMS ${ }^{14} \mathrm{C}$ age with calibrated age BP correspondence of the dated material collected in lakes Pentecôte and Walker.

\begin{tabular}{|c|c|c|c|c|c|}
\hline $\begin{array}{l}\text { Core name/ } \\
\text { location }\end{array}$ & Material & $\begin{array}{l}\text { Depth } \\
\text { in } \\
\text { core } \\
(\mathrm{cm})\end{array}$ & $\begin{array}{l}\text { Laboratory } \\
\text { number }\end{array}$ & $\begin{array}{l}\text { Conventional } \\
{ }^{14} \mathrm{C} \text { Age BP } \\
(\mathrm{yr} \mathrm{BP})\end{array}$ & $\begin{array}{l}\text { Calibrated } \\
\text { age BP (cal } \\
\text { BP) }\end{array}$ \\
\hline $\begin{array}{l}\text { WA15-08D- } \\
\text { U }\end{array}$ & $\begin{array}{l}\text { Wood } \\
\text { fragment }\end{array}$ & 647 & UCIAMS-161066 & $7060 \pm 25$ & $7845-7950$ \\
\hline PC15-04B-P & Bulk & 101 & UCIAMS-162978 & $7240 \pm 25$ & $8000-8160$ \\
\hline
\end{tabular}

the Goldthwait Sea after deglaciation. The good connectivity with the open coast and the elevation of the lake probably favored a rapid opening of the valley. The swath bathymetry imagery and aerial photography (Fig. 5) reveal the presence of bathymetric highs that induced short-term stabilization of the ice margin during its retreat. Being located at the same elevation, lakes Pasteur and Pentecôte were probably isolated in glaciolacustrine basin around the same time. Subbottom profiles in Lake Pasteur show a thick ( $\geq 50 \mathrm{~m}$ ) drape of rhythmically laminated acoustic sediments (U3; Fig. 8) deposited during deglaciation. Complete deglaciation of the lakes Pasteur and Pentecôte watersheds were probably synchronous due to the similar northward extent of their respective watershed (Fig. 12F).

\subsection{Deglacial transgression and the following forced regression}

The morphosedimentary data presented here indicate that lakes Pentecôte and Pasteur were occupied by the Goldthwait Sea during deglaciation; such a situation was probably not the case for Lake Walker where the ice margin blocked the entrance of the fjord valley. The possible limit of marine areal extent upstream in the lakes Pentecôte and Pasteur watershed is difficult to establish due to the complex diachronic interactions between ice margin retreat, marine transgression and glacio-isostatic differential rebound. Differential re-

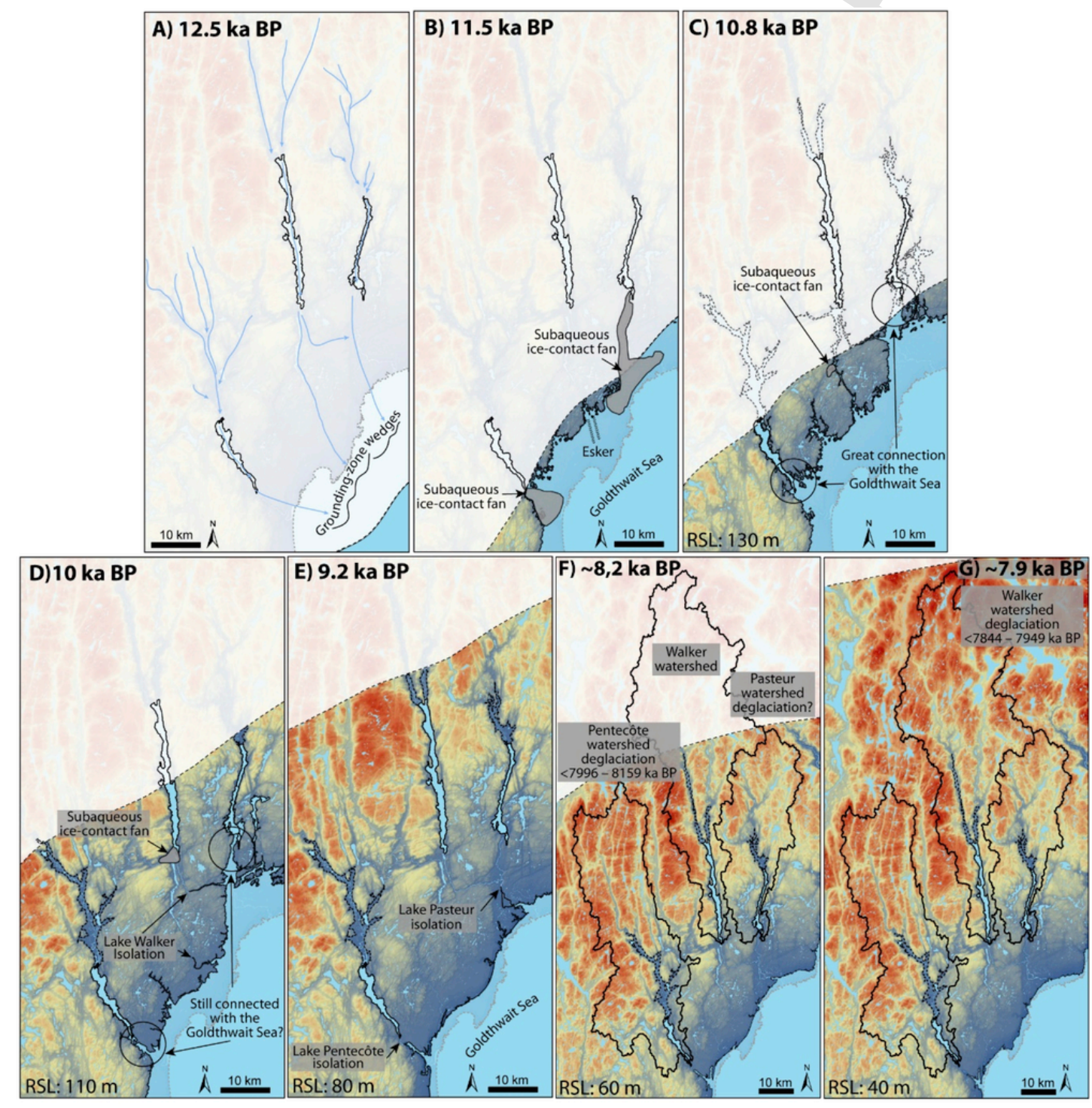

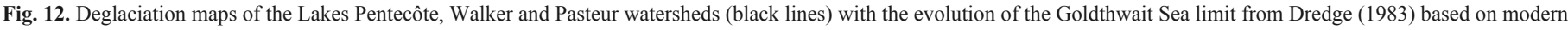

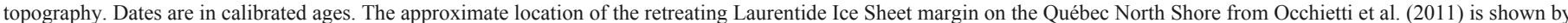

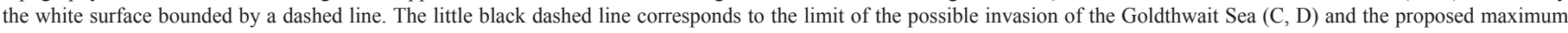
extension of the glaciolacustrine basins (E, F, and G). Note that the scale decrease in F and G. 


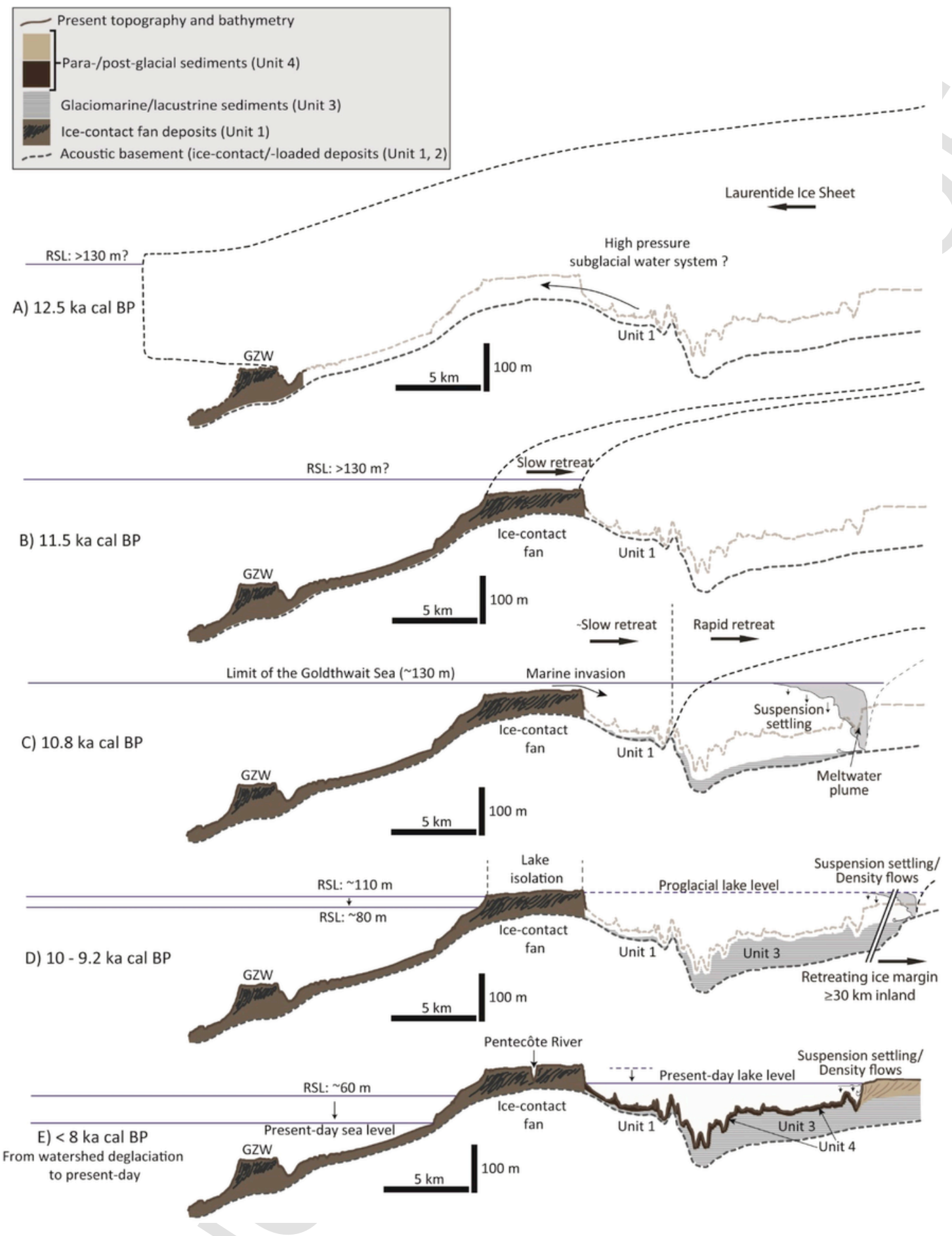

Fig. 13. Deglaciation model of Lake Pentecôte. See text for details and Fig. 1 for transect location.

bound may have caused the differing marine limits between the coastal area and the head of the structural valleys of the lakes. Moreover, marine sediments have been reworked and overlain by glaciofluvial and fluvial deposits, making their identification difficult. Nevertheless, the identification of a marine deltaic deposit upstream Lake Pentecôte valley (Dredge, 1983) provides evidence for marine waters in the sector.

\subsection{Para- and post-glacial sedimentary environments}

Deglaciation of the watersheds of lakes Pentecôte, Walker and Pasteur coincided with the shutdown of direct glacigenic sediment supply into the lakes from glacial meltwater sources (U3). The establishment of paraglacial sedimentation (lower part of U4) (Fig. 12F and $\mathrm{G}, 13 \mathrm{E}, 14 \mathrm{E}$ ) began when the LIS margin retreated from the watersheds, as sediment delivery to the lake was then mainly dominated 


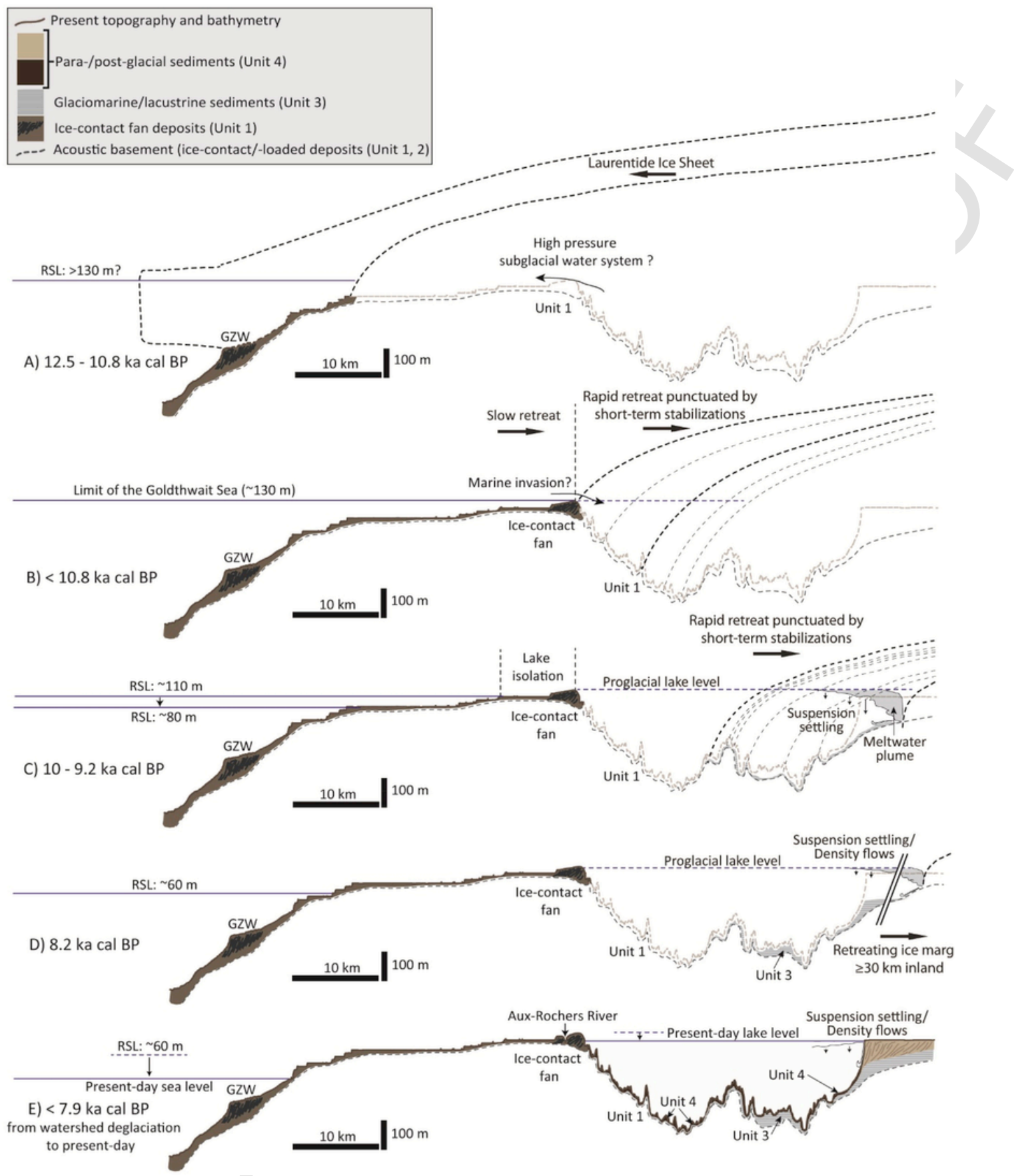

Fig. 14. Deglaciation model of Lake Walker. See text for details and Fig. 1 for transect location.

by reworking and transport of glacigenic deposits along the river banks (Church and Ryder, 1972; Church and Slaymaker, 1989; Ballantyne, 2002; Hein et al., 2014; Dietrich et al., 2017a). From 10 ka cal BP, the study area was ice-free and being slowly colonized by a periglacial tundra vegetation which was progressively replaced by dense forest (Richard and Grondin, 2009). The development of postglacial forest and soils led to the stabilization of the watersheds, which limited sediment availability and transport, and resulted in the deposition of organic-rich fine sediments (i.e., gyttja). The development of the long lake-head river delta plain during deglaciation generated a constant source of detritic fluvial sediment supply during the
Holocene, leading to the formation of crescentic and creeping bedforms on the sublacustrine deltas slope (Normandeau et al., 2016a). The evolution of the bedforms between 2011 and 2016 (Fig. 4) indicates that the lake deltas are still active, therefore contributing to the formation of laminae in U4. The migration of the crescentic bedforms in an upslope direction confirms that they are cyclic steps or transitional upper-flow regime bedforms between antidunes and cyclic steps sensu Covault et al. (2017) formed by sediment density flows as initially described by Normandeau et al. (2016a).

The para- and post-glacial sediments (U4) in lakes Pentecôte (Fig. 11A) and Walker (Fig. 11C) is delimited by a sharp lower contact 
with the underlying deglacial sediments (U3), indicating an abrupt switch-off of direct glaciogenic sediment supply following complete deglaciation of the lake watersheds (Dietrich et al., 2017a; Normandeau et al., 2017). The rhythmically laminated sediments downward U4 have strong similarities with clastic-organic varves deposited in paraglacial conditions (Ridge et al., 2012; Zolitschka et al., 2015). Sedimentation in the lakes then shifted to a postglacial sedimentation regime characterized by the deposition of gyttja sediments containing diffuse laminae (Fig. 11A). These sediments have been typically observed in modern Québec lakes situated on the Canadian Shield where hemipelagic settling sediment dominates due to a low fluvial input (Shilts and Clague, 1992; Shilts et al., 1992; Ouellet, 1997; Turgeon et al., 2003; Normandeau et al., 2013, 2017; Lajeunesse et al., 2017).

\subsection{Deglacial, paraglacial and postglacial mass-movements}

The high-resolution bathymetry imagery, subbottom profiles and sediment cores reveal that mass-movement landforms and deposits are present within the glaciomarine and/or glaciolacustrine unit (U3) and less frequently within the paraglacial and postglacial unit (U4). High rates of glacio-isostatic rebound during the early phase of deglaciation might have generated strong earthquakes (Shilts et al., 1992; Ouellet, 1997; Hill et al., 1999; Stewart et al., 2000; Beck et al., 2001; Lajeunesse and Allard, 2002; Turgeon et al., 2003; St-Onge et al., 2004; Normandeau et al., 2013; Brooks, 2016; Lajeunesse et al., 2017), which would have triggered the mass-movements observed in U3 in the three lakes. Mass-movements that occurred during and/or shortly following deglaciation of the lakes could also have been triggered by overload of sediment and dewatering of rapidly deposited sediments (e.g., Lajeunesse and Allard, 2002; Lajeunesse et al., 2017). Variations in the lake level, such as a rapid lake-level fall following outburst events at the lake end, might also be potential triggering mechanisms (Mullins and Halfman, 2001; Monecke et al., 2004).

Throughout the Holocene, the three studied lakes were conducive to gravitational processes. RDLs observed in postglacial sediments in the three lakes could have been produced by sediment density flows, mass-movements and floods or could also have been produced by earthquake-triggered mass-movements (St-Onge et al., 2012) from the Lower St. Lawrence Seismic Zone, as observed in lakes located near other active seismic zones (Doig, 1990; Lajeunesse et al., 2008, 2017; Normandeau et al., 2013; Doughty et al., 2014).

\section{Conclusions}

The analysis of high-resolution swath bathymetry imagery, acoustic subbottom profiles and sediment cores collected in fjord-lakes Pentecôte, Walker and Pasteur (Québec North Shore) allow the establishment of a conceptual model of the evolution of coastal fjords as they are progressively deglaciated and glacio-isostatically uplifted to form fjord-lake basins. The key results of this study are:

- The key geographical location and the limnogeological context of lakes Pentecôte, Walker and Pasteur allowed the preservation of a continuous and high-resolution sedimentary record that provides an exceptional potential for paleoenvironmental reconstructions since the last glaciation, and possibly before;

- Moraines observed on the lake floor of fjord-lakes Pentecôte, Walker and Pasteur and in their structural valleys indicate a deglaciation punctuated by short-term ice margin stabilizations. The large accommodation space created by the rapid ice retreat in these deep basins prevented their overfilling, especially in Lake
Walker, allowing the lakes to exist and to preserve laminated sediment archives until today;

- During deglaciation, the three fjord-lakes acted as sediment traps and were filled by a thick sequence of rhythmically laminated silts and clays (U3) deposited in glaciomarine and/or glaciolacustrine environments that have been highly disturbed by mass-movements;

- Lakes Pentecôte, Walker and Pasteur reveal in the upper $\sim 4-\sim 8 \mathrm{~m}$ of their sediment infill a continuous para-to post-glacial sediment record (U4). The transition between U3 and U4 is associated with a complete retreat of the Laurentide Ice Sheet margin and the gradual stabilization of the terrestrial postglacial landsystem by the development of a forest cover;

- The boundary between deglaciation of the lakes Pentecôte and Walker watersheds and the establishment of para- and post-glacial conditions is dated at $<8000-8160$ and $<7845-7950$ cal BP, respectively. These new dates are consistent with the Occhietti et al. (2011) deglaciation model and allow refining the position of the retreating Laurentide Ice Sheet margin inland on the North Shore of the Gulf of St. Lawrence.

Future work in these lakes should be directed towards the high-resolution analysis of long sediment cores and the acquisition of low-frequency acoustic subbottom profiles in order to achieve greater penetration into the sediments, especially in deposits located below the glaciomarine/glaciolacustrine unit (U3).

\section{Unlisted references}

Hambrey, 1994; Howe et al., 2010; Evans et al., 2002; Schumann et al., 2012; Dowdeswell and Vásquez, 2013; Dowdeswell et al., 2014; Cowan et al., 2010; Forwick and Vorren, 2010; Bertrand et al., 2012; Breuer et al., 2013; Hjelstuen et al., 2013; Kempf et al., 2013; Hodgson et al., 2014; Flink et al., 2015; Batterson et al., 1993; Batterson and Catto, 2001; Van Rensbergen et al., 1999; Fanetti et al., 2008; Hilbe et al., 2011; Turner et al., 2012; Pinson et al., 2013; Vogel et al., 2013; Kastner et al., 2010; Waldmann et al., 2010; Nzekwe et al., in press; Lajeunesse et al., 2007.

\section{Acknowledgments}

This study was supported by the Natural Sciences and Engineering Research Council of Canada through Discovery and Ship-time grants to P.L., P.F. and G.S., by the Canadian Foundation for Innovation and the Ministère de l'éducation du Québec through equipment grants to P.L. and by the gs3:Fonds de Recherche du Québec - Nature et Technologies to P.L, P.F. and G.S. We thank Jean-Philippe Jenny, Thibault Labarre, Louis-Frédéric Daigle, Mathieu Des Roches (INRS), Gabriel Joyal, Annie-Pier Trottier, Etienne Brouard, François-Xavier L'Heureux-Houde, Geneviève Philibert (U. Laval), Edouard Philippe (UQAR) and the R/V Louis-Edmond-Hamelin captain Daniel Deschênes for their assistance during fieldwork, laboratory and helpful discussions. We are grateful to the staff at La Réserve faunique de Port-Cartier-Sept-Îles and the Village d'accueil de Rivière-Pentecôte for their hospitality and permission to access the lakes. We also thank the anonymous reviewers for providing constructive comments on this paper. Finally, many thanks to Monique Gagnon and Charles Smith for revising the English of an earlier version of the manuscript.

\section{References}

Baeten, N.J., Forwick, M., Vogt, C., Vorren, T.O., 2010. Late weichselian and Holocene sedimentary environments and glacial activity in billefjorden, svalbard Spec. Publ. Geol. Soc. Lon. 344, 207-223. 
Ballantyne, C.K., 2002. Paraglacial geomorphology. Quat. Sci. Rev. 21, 1935-2017.

Beck, C., Van Rensbergen, P., De Batist, M., Berthier, F., Lallier, S., Manalt, F., 2001. The late Quaternary sedimentary infill of Lake Annecy (northwestern Alps): an overview from two seismic-reflection surveys. J. Paleolimnol. 25, 149-161.

Boes, E., 2014. Reconstruction of the Southern Alaskan Climate during the Last 700 Years, Based on a Multi-proxy Analysis of Annually Laminated Lake Records. MSc thesis in geology Ghent University, Belgique, 156.

Boyd, B., Anderson, J., Wellner, J., Fernández, R., 2008. The sedimentary record of glacial retreat, Marinelli Fjord, Patagonia: regional correlations and climate ties. Mar. Geol. 255, 165-178.

Brennand, T.A., 2000. Deglacial meltwater drainage and glaciodynamics: inferences from Laurentide eskers, Canada. Geomorphology 32, 263-293.

Brooks, G.R., 2016. Evidence of late glacial paleoseismicity from submarine landslide deposits within Lac Dasserat, northwestern Quebec, Canada. Quat. Res. 86, 184-199.

Church, M., Ryder, J.M., 1972. Paraglacial sedimentation: a consideration of fluvial processes conditioned by glaciation. Geol. Soc. Am. Bull. 83, 3059-3072.

Church, M., Slaymaker, O., 1989. Disequilibrium of Holocene sediment yield in glaciated British Columbia. Nature 337, 452-454.

Covault, J.A., Kostic, S., Paull, C.K., Sylvester, Z., Fildani, A., 2017. Cyclic steps and related supercritical bedforms: building blocks of deep-water depositional systems, western North America. Mar. Geol.(in press)

Desloges, J.R., Gilbert, R., 1995. The sedimentary record of Moose Lake: implications for glacier activity in the Mount Robson area, British Columbia. Can. J. Earth Sci. $32,65-78$.

Desloges, J.R., Gilbert, R., 1998. Sedimentation in chilko lake: a record of the geomorphic environment of the eastern coast mountains of British Columbia, Canada. Geomorphology 25, 75-91.

Dietrich, P., Ghienne, J.-F., Schuster, M., Lajeunesse, P., Nutz, A., Deschamps, R., Roquin, C., Duringer, P., 2017a. From outwash to coastal systems in the Portneuf-Forestville deltaic complex (Québec North Shore): anatomy of a forced regressive deglacial sequence. Sedimentology 64, 1044-1078.

Dietrich, P., Ghienne, J.F., Normandeau, A., Lajeunesse, P., 2017b. Reconstructing ice-margin retreat using delta morphostratigraphy. Sci. Rep. 7 (1), 16936.

Dionne, J.-C., 2001. Relative sea-level changes in the St. Lawrence estuary from deglaciation to present day. Spec. Pap. Geol. Soc. Lon. 351, 271-284.

Doig, R., 1990. $2300 \mathrm{yr}$ history of seismicity from silting events, in Lake Tadoussac, Charlevoix, Quebec. Geology 18, 820-823.

Doughty, M., Eyles, N., Eyles, C., 2013. High-resolution seismic reflection profiling of neotectonic faults in lake timiskaming, timiskaming graben, Ontario-Quebec, Canada. Sedimentology 60, 983-1006.

Doughty, M., Eyles, N., Eyles, C., Wallace, K., Boyce, J., 2014. Lake sediments as natural seismographs: earthquake-related deformations (seismites) in central Canadian lakes. Sediment. Geol. 313, 45-67.

Dredge, L.A., 1983. Surficial geology of the sept-iles area, Quebec north shore. Geological survey of Canada. Memoir 408, 40.

Dubois, J.-M.M., Dionne, J.-C., 1985. The Quebec North Shore moraine system: a major feature of Late Wisconsin deglaciation. Spec. Pap. Geol. Soc. Lon. 197, $125-134$.

Evans, D.J.A., 2013. Glacial landforms, sediments/Glaciolacustrine A2-Elias, Scott A In: Mock, C.J. (Ed.), Encyclopedia of Quaternary Science, second ed. Elsevier, Amsterdam, pp. 43-51.

Eyles, N., Mullins, H.T., Hine, A.C., 1990. Thick and fast: sedimentation in a Pleistocene fiord lake of British Columbia, Canada. Geology 18, 1153-1157.

Eyles, N., Mullins, H.T., Hine, A.C., 1991. The seismic stratigraphy of Okanagan Lake, British Columbia; a record of rapid deglaciation in a deep 'fiord-lake'basin. Sediment. Geol. 73, 13-41.

Geirsdóttir, , Miller, G.H., Wattrus, N.J., Bjo“rnsson, H., Thors, K., 2008. Stabilization of glaciers terminating in closed water bodies: evidence and broader implications. Geophys. Res. Lett. 35, L17502.

Gilbert, R., Butler, R.D., 2004. The physical limnology and sedimentology of meziadin lake, northern British Columbia, Canada. Arctic Antarct. Alpine Res. 36, 33-41.

Gilbert, R., Desloges, J.R., 2005. The record of glacial lake champagne in kusawa lake, southwestern yukon territory. Can. J. Earth Sci. 42, 2127-2140.

Gilbert, R., Crookshanks, S., Hodder, K.R., Spagnol, J., Stull, R.B., 2006a. The record of an extreme flood in the sediments of montane Lillooet Lake, British Columbia: implications for paleoenvironmental assessment. J. Paleolimnol. 35, 737-745.

Gilbert, R., Desloges, J.R., Lamoureux, S.F., Serink, A., Hodder, K.R., 2006b. The geomorphic and paleoenvironmental record in the sediments of Atlin Lake, northern British Columbia. Geomorphology 79, 130-142.

Gilbert, R., Desloges, J.R., 2012. Late glacial and Holocene sedimentary environments of quesnel lake, British Columbia. Geomorphology 179, 186-196.

Guyard, H., Francus, P., St-Onge, G., Hausmann, S., Pienitz, R., 2014. Microfacies and microstructures of subglacial and deglacial sediments from the pingualuit crater lake (Ungava Peninsula, Canada). Can. J. Earth Sci. 51, 1084-1096.

Guyard, H., St-Onge, G., Pienitz, R., Francus, P., Zolitschka, B., Clarke, G.K., Hausmann, S., Salonen, V.-P., Lajeunesse, P., Ledoux, G., 2011. New insights into late pleistocene glacial and postglacial history of northernmost ungava (Canada) from pingualuit crater lake sediments. Quat. Sci. Rev. 30, 3892-3907.
Hein, C.J., FitzGerald, D., Buynevich, I., Van Heteren, S., Kelley, J., 2014. Evolution of paraglacial coasts in response to changes in fluvial sediment supply. Spec. Publ. Geol. Soc. Lon. 388, 247-280.

Hein, F.J., Syvitski, J.P., Dredge, L.A., Long, B.F., 1993. Quaternary sedimentation and marine placers along the north shore, Gulf of St. Lawrence. Can. J. Earth Sci. $30,553-574$.

Heirman, K., De Batist, M., Arnaud, F., De Beaulieu, J.-L., 2012. Seismic stratigraphy of the late Quaternary sedimentary infill of Lac d'Armor (Kerguelen archipelago): a record of glacier retreat, sedimentary mass wasting and southern Westerly intensification. Antarct. Sci. 24, 608-618.

Hill, P.R., Simard, A., Héquette, A., 1999. High-resolution seismic stratigraphy of late Quaternary deposits in Manitounouk Sound, northern Quebec: effects of rapid postglacial emergence. Can. J. Earth Sci. 36, 549-563.

Holtedahl, H., 1967. Notes on the formation of fjords and fjord-valleys. Geogr. Ann. Phys. Geogr. 188-203.

King, G.A., 1985. A standard method for evaluating radiocarbon dates of local deglaciation: application to the deglaciation history of southern Labrador and adjacent Québec. Géogr. Phys. Quat. 39, 163-182.

Lajeunesse, P., Allard, M., 2002. Sedimentology of an ice-contact glaciomarine fan complex, Nastapoka Hills, eastern Hudson Bay, northern Québec. Sediment. Geol. $152,201-220$.

Lajeunesse, P., St-Onge, G., Randall, K., Moreau-Labrecque, A., 2008. Mouvements de masse subaquatiques postglaciaires au lac Jacques-Cartier, Réserve faunique des Laurentides (Québec): résultats préliminaires. In: Comptes rendus de la 4e Conférence canadienne sur les géorisques: des causes à la gestion. Presse de l'Université Laval, Québec, pp. 313-321.

Lajeunesse, P., 2014. Buried preglacial fluvial gorges and valleys preserved through Quaternary glaciations beneath the eastern Laurentide Ice Sheet. Geol. Soc. Am. Bull. 126, 447-458.

Lajeunesse, P., 2016. Late-quaternary grounding-zone wedges, NW Gulf of St. Lawrence, eastern Canada. In: Dowdeswell, J., Canals, M., Jakobsson, M., Todd, B., Dowdeswell, E., Haan, K. (Eds.), Atlas of Submarine Glacial Landforms: Modern, Quaternary and Ancient. Geological Society of London Memoir, paper 897.

Lajeunesse, P., Sinkunas, B., Morissette, A., Normandeau, A., Joyal, G., St-Onge, G., Locat, J., 2017. Large-scale seismically-induced mass-movements in a former glacial lake basin: lake Témiscouata, northeastern Appalachians (eastern Canada). Mar. Geol. 384, 120-130.

Lamontagne, M., 1987. Seismic activity and structural features in the Charlevoix region, Quebec. Can. J. Earth Sci. 24, 2118-2129.

Lamontagne, M., Keating, P., Perreault, S., 2003. Seismotectonic characteristics of the Lower St. Lawrence Seismic Zone, Quebec: insights from geology, magnetics, gravity, and seismics. Can. J. Earth Sci. 40, 317-336.

Mangerud, J., Goehring, B.M., Lohne, Ø.S., Svendsen, J.I., Gyllencreutz, R., 2013. Collapse of marine-based outlet glaciers from the scandinavian ice sheet. Quat. Sci. Rev. 67, 8-16.

Monecke, K., Anselmetti, F.S., Becker, A., Sturm, M., Giardini, D., 2004. The record of historic earthquakes in lake sediments of Central Switzerland. Tectonophysics $394,21-40$.

Moukhsil, A., Nadeau, J., Québec, G., 2011. Géologie de la partie orientale de la région de Baie-Comeau (partie ouest de 22G). Ministère de l'Energie et des Ressources Naturelles, Québec, RG 2011-02, 36 pp.

Mullins, H.T., Hinchey, E.J., 1989. Erosion and infill of New York finger lakes: implications for Laurentide ice sheet deglaciation. Geology 17, 622-625.

Mullins, H.T., Eyles, N., Hinchey, E.J., 1991. High-Resolution Seismic Stratigraphy of Lake Mcdonald, Glacier National Park, Montana, U.S.A. Arct. Alp. Res. 23, 311-319.

Mullins, H.T., Eyles, N., 1996. Subsurface geologic investigations of New York Finger Lakes: implications for late Quaternary deglaciation and environmental change. Spec. Pap. Geol. Soc. Am. 311, 1-35.

Mullins, H.T., 1998. Holocene lake level and climate change inferred from marl stratigraphy of the Cayuga Lake basin, New York. J. Sediment. Res. 68, 569-578.

Mullins, H.T., Halfman, J.D., 2001. High-resolution seismic reflection evidence for middle Holocene environmental change, Owasco Lake, New York. Quat. Res. 55, 322-331.

Nasmith, H., 1962. Late glacial history and surficial deposits of the Okanagan Valley, British Columbia. Br. Columbia Dep. Mine. Petrol. Resour.

Normandeau, A., Lajeunesse, P., Philibert, G., 2013. Late-Quaternary morphostratigraphy of Lake St-Joseph (southeastern Canadian Shield): Evolution from a semi-enclosed glacimarine basin to a postglacial lake. Sediment. Geol. 295, 38-52.

Normandeau, A., Lajeunesse, P., Gagnon-Poiré, A., Francus, P., 2016a. Morphological expression of bedforms formed by supercritical sediment density flows in four fjord-lake deltas of the south-eastern Canadian Shield (Eastern Canada). Sedimentology $63,2106-2129$.

Normandeau, A., Joyal, G., Lajeunesse, P., Francus, P., Lamoureux, S., Lapointe, F., 2016b. Late-Holocene Mass Movements in High Arctic East Lake, Melville Island (Western Canadian Arctic Archipelago). In: Submarine Mass Movements and Their Consequences. Springer International Publishing, pp. 311-320.

Normandeau, A., Lajeunesse, P., Trottier, A.-P., Gagnon-Poiré, A., Pienitz, R., 2017. Sedimentation in isolated glaciomarine embayments during glacio-isostatically in- 
duced relative sea level fall (northern Champlain Sea basin). Can. J. Earth Sci. 54 (10), 1049-1062.

Nutz, A., Ghienne, J.F., Schuster, M., Certain, R., Robin, N., Roquin, C., Raynal, O., Bouchette, F., Duringer, P., Cousineau, P.A., 2014. Seismic-stratigraphic record of a deglaciation sequence: from the marine Laflamme Gulf to Lake Saint-Jean (late Quaternary, Québec, Canada). Boreas 43, 309-329.

Ó Cofaigh, C., Dowdeswell, J.A., 2001. Laminated sediments in glacimarine environments: diagnostic criteria for their interpretation. Quat. Sci. Rev. 20, 1411-1436.

Occhietti, S., 2007. The Saint-Narcisse morainic complex and early Younger Dryas events on the southeastern margin of the Laurentide Ice Sheet. Géogr. Phys. Quat. 61, 89-117.

Occhietti, S., Parent, M., Lajeunesse, P., Robert, F., Govare, E., 2011. Late Pleistocene-early Holocene decay of the Laurentide ice sheet in Québec-Labrador. Dev. Quat. Sci. 15, 601-630.

Ouellet, M., 1997. Lake sediments and Holocene seismic hazard assessment within the St. Lawrence Valley, Québec. Geol. Soc. Am. Bull. 109, 631-642.

Powell, R.D., 1983. Glacial-marine Sedimentation Processes and Lithofacies of Temperate Tidewater Glaciers, Glacier Bay, Alaska, Glacial-marine Sedimentation. Springer, 185-232.

Reimer, P.J., Bard, E., Bayliss, A., Beck, J.W., Blackwell, P.G., Ramsey, C.B., Buck, C.E., Cheng, H., Edwards, R.L., Friedrich, M., 2013. IntCal13 and Marine13 radiocarbon age calibration curves $0-50,000$ years cal BP. Radiocarbon 55 , 1869-1887.

Richard, P., Grondin, P., 2009. Histoire postglaciaire de la végétation. In: Ordre des ingénieurs forestiers du Québec, Manuel de foresterie, 2e édition Éditions MultiMondes (Québec), pp. 170-176, ouvrage collectif.

Ridge, J.C., Balco, G., Bayless, R.L., Beck, C.C., Carter, L.B., Dean, J.L., Voytek, E.B., Wei, J.H., 2012. The new North American Varve Chronology: A precise record of southeastern Laurentide Ice Sheet deglaciation and climate, 18.2-12.5 kyr BP, and correlations with Greenland ice core records. Am. J. Sci. 312, $685-722$.

Shaw, J., Gareau, P., Courtney, R., 2002. Palaeogeography of Atlantic Canada 13-0kyr. Quat. Sci. Rev. 21, 1861-1878.

Shilts, W., Clague, J.J., 1992. Documentation of earthquake-induced disturbance of lake sediments using subbottom acoustic profiling. Can. J. Earth Sci. 29 , $1018-1042$

Shilts, W., Rappol, M., Blais, A., 1992. Evidence of late and postglacial seismic activity in the Temiscouata-Madawaska Valley, Quebec-New Brunswick, Canada. Can. J. Earth Sci. 29, 1043-1069.

St-Onge, G., Chapron, E., Mulsow, S., Salas, M., Viel, M., Debret, M., Foucher, A. Mulder, T., Winiarski, T., Desmet, M., 2012. Comparison of earthquake-triggered turbidites from the Saguenay (Eastern Canada) and Reloncavi (Chilean margin) Fjords: Implications for paleoseismicity and sedimentology. Sediment. Geol. 243, 89-107.

St-Onge, G., Mulder, T., Francus, P., Long, B., 2007. Continuous Physical Properties of Cored Marine Sediments. Proxies in Late Cenozoic Paleoceanography. Elsevier, 63-98.

St-Onge, G., Mulder, T., Piper, D.J., Hillaire-Marcel, C., Stoner, J.S., 2004. Earthquake and flood-induced turbidites in the Saguenay Fjord (Québec): a Holocene paleoseismicity record. Quat. Sci. Rev. 23, 283-294.

Stewart, I.S., Sauber, J., Rose, J., 2000. Glacio-seismotectonics: ice sheets, crustal deformation and seismicity. Quat. Sci. Rev. 19, 1367-1389.

Stuiver, M., Reimer, J., 1993. Extended 14C data base and revised CALIB 3.014 C age calibration program. Radiocarbon 35, 215-230.

Syvitski, J., Praeg, D., 1987. Sedimentology of Arctic Fjords Experiment: Data Report, vol. 3, 54, Canadian Data Report of Hydrography and Ocean Sciences.

Syvitski, J.P., Praeg, D.B., 1989. Quaternary sedimentation in the St. Lawrence Estuary and adjoining areas, Eastern Canada: An overview based on high-resolution seismo-stratigraphy. Géogr. Phys. Quat. 43, 291-310.

Syvitski, J.P., Shaw, J., 1995. Sedimentology and geomorphology of fjords. Dev. Sedimentol. 53, 113-178.

Tunnicliffe, J.O.N., Church, M., Enkin, R.J., 2012. Postglacial sediment yield to Chilliwack Lake, British Columbia, Canada. Boreas 41, 84-101.

Turgeon, S., Dubois, J.-M., Ouellet, M., Poulin, A., 2003. Sismostratigraphie des lacs Brompton, Memphrémagog et Massawippi, sud du Québec, Canada: déglaciation et paléoenvironnements sédimentaires du tardi-Quaternaire appalachien/Seismostratigraphy of Lakes Brompton, Memphrémagog and Massawippi, southern Québec, Canada: Late Quaternary déglaciation and sedimentary palaeoenvironments. Géomorphol. Relief, Process. Environ. 9, 13-31.

Ullman, D.J., Carlson, A.E., Hostetler, S.W., Clark, P.U., Cuzzone, J., Milne, G.A., .. Caffee, M., 2016. Final Laurentide ice-sheet deglaciation and Holocene climate-sea level change. Quat. Sci. Rev. 152, 49-59.

Van Daele, M., Bertrand, S., Meyer, I., Moernaut, J., Vandoorne, W., Siani, G., Tanghe, N., Ghazoui, Z., Pino, M., Urrutia, R., De Batist, M., 2016. Late Quaternary evolution of Lago Castor (Chile, $45.6^{\circ} \mathrm{S}$ ): Timing of the deglaciation in north ern Patagonia and evolution of the southern westerlies during the last $17 \mathrm{kyr}$. Quat. Sci. Rev. 133, 130-146.

Zolitschka, B., Francus, P., Ojala, A.E., Schimmelmann, A., 2015. Varves in lake sediments-a review. Quat. Sci. Rev. 117, 1-41. 